\title{
LEARNING FROM LIVED EXPERIENCE: AUSTRALIA'S LEGAL RESPONSE TO FORCED MARRIAGE
}

\author{
FRANCES SIMMONS* AND GRACE WONG**
}

\begin{abstract}
Since the criminalisation of forced marriage in Australia in 2013, the number of cases reported to Australian authorities has risen sharply. This article draws on a qualitative study with eight survivors of forced marriage in Australia to explore survivors understanding of the legal concepts of forced marriage and family violence; experiences of coercion and control in the lead up to, and within, a forced marriage; the obstacles survivors encountered when they sought help; their reflections on justice and the limitations of legal responses to forced marriage; and how survivors can shape law and policy reform. The findings of this study underline the need to reframe Australia's response to forced marriage to address the complex processes of coercion and control which lead to forced marriage and to create meaningful opportunities for survivors to shape the design, implementation and evaluation of legal and policy responses to forced marriage.
\end{abstract}

\section{INTRODUCTION}

Drawing on a qualitative study with eight survivors of forced marriage, ${ }^{1}$ this article examines Australia's legal response to forced marriage. Australia's initial response

* Visiting Scholar, University of Technology Sydney Law Faculty; PhD Candidate, Monash University; Conjoint Lecturer, University of Newcastle Law School. Unless otherwise indicated, the views expressed in this article are the personal views of the author.

** Unless otherwise indicated, the views expressed in this article belong to the author, in her former capacity as an employee with Anti-Slavery Australia, University of Technology Sydney. The authors would like to thank all the survivors who participated in this study for the strength, determination and generosity they demonstrated in sharing their unique insights into the lived experience of those affected by forced marriage and their views about how Australia could improve its legal response to forced marriage. This study was supported by a University of Technology Sydney Social Impact Grant, a University of Newcastle New Staff Grant, and Norton Rose Fulbright law firm. The authors are grateful to Yat Hing Elsie Cheung for her excellent research assistance and to the anonymous referees for their helpful comments on the draft article. The authors would also like to thank the Australian Red Cross and the other organisations who shared information about this study with potential participants as well as all those individuals who generously provided advice and feedback during the development of this study. Any errors are the responsibility of the authors.

1 We use the terms 'survivor', 'victim' and 'interviewee' interchangeably in this article, depending on the context of our analysis. We acknowledge that individuals who have experienced or been affected by forced marriage may not self-identify with any or all of the terms 'victim', 'survivor' and 'victim-survivor'. 
to forced marriage evolved in a narrow law enforcement framework without paying attention to the views of people with lived experience of forced marriage. Since the introduction of a federal offence of forced marriage in 2013, which criminalises conduct causing a person to enter into a marriage to which that person does not freely and fully consent, the number of cases reported to Australian authorities has risen sharply. However, the prevailing focus on criminal justice interventions has not resulted in convictions: forced marriage remains poorly understood and likely underreported. Calls for greater investment in community-led prevention initiatives, and movement towards a federal scheme of forced marriage protection orders, present opportunities to reframe Australia's response to forced marriage.

After outlining Australia's response to forced marriage, we explore five themes from our interviews with survivors: the cumulative impact of experiences of coercion and control; survivors' understandings of the terms 'forced marriage' and 'family violence'; experiences of help-seeking; perspectives on seeking justice and legal responses to forced marriage; and the role of survivors in informing the development of responses to forced marriage. While participants' experiences of forced marriage were diverse, all participants agreed that responses to forced marriage should be informed by the expertise and experience of survivors. The study reveals the limitations of current legal responses to forced marriage and underlines the importance of creating meaningful opportunities for survivors to shape Australia's response to forced marriage.

\section{DEFINING AND IDENTIFYING FORCED MARRIAGE}

\section{A Defining Forced Marriage}

Forced marriage is a human rights abuse and a form of gender-based violence that disproportionately impacts women and children. ${ }^{2}$ Although international law does not specifically define 'forced marriage', the right of every adult to choose who they marry is enshrined in international human rights law. Forced marriage is recognised as a slavery-like practice ${ }^{3}$ and a consequence of trafficking in

2 In 2017, the International Labour Organization included forced marriage in its global estimates of 'modern slavery', estimating that in 2016, 15.4 million people were living in situations of forced marriage, $84 \%$ of whom were women and girls: International Labour Organization and Walk Free Foundation, Global Estimates of Modern Slavery: Forced Labour and Forced Marriage (Report, 19 September 2017) 10. Cf Anne T Gallagher, 'What's Wrong with the Global Slavery Index?' (2017) 8 AntiTrafficking Review 90.

3 Human Rights Council, Preventing and Eliminating Child, Early and Forced Marriage: Report of the Office of the United Nations High Commissioner for Human Rights, UN Doc A/HRC/26/22 (2 April 2014) 4 [8], 8 [21], 10 [27]; Supplementary Convention on the Abolition of Slavery, the Slave Trade, and Institutions and Practices Similar to Slavery, opened for signature 7 September 1956, 266 UNTS 3 (entered into force 30 April 1957) art 1 ('Supplementary Convention'). The 1956 Supplementary Convention does not use the phrase 'forced marriage' or 'servile marriage' but requires States to criminalise 'any institution or practice whereby: (i) A woman, without the right to refuse, is promised or given in marriage on payment of a consideration in money or in kind to her parents, guardian, family or any other person or group; or (ii) The husband of a woman, his family, or his clan, has the right to transfer 
persons, ${ }^{4}$ and the United Nations ('UN') Sustainable Development Goals exhort States to 'eliminate all harmful practices, such as child, early and forced marriage'. ${ }^{5}$ Acknowledging that forced marriage is a form of gender-based violence $^{6}$ focuses attention on the structures, practices and attitudes that leave women and girls particularly vulnerable to forced marriage, ${ }^{7}$ including gender discrimination in marriage laws, ${ }^{8}$ the lack of effective legal remedies to address gender-based violence, and gender inequality. While forced marriage can be understood within the context of patriarchal power structures that exist at societal and familial levels, viewing specific instances of forced marriage through an intersectional lens makes visible the ways in which existing legal structures and societal discrimination on the grounds of race, disability, sexual orientation and immigration status can contribute to a person's vulnerability to forced marriage ${ }^{9}$ and interfere with the right of every person to freely choose a spouse. ${ }^{10}$

The UN Committee on the Rights of the Child and Committee on the Elimination of Discrimination against Women describe forced marriage as a marriage in which one or both parties 'have not personally expressed their full and free consent to

her to another person for value received or otherwise; or (iii) A woman on the death of her husband is liable to be inherited by another person': at art 1(c).

4 United Nations Office on Drugs and Crime, 'Interlinkages between Trafficking in Persons and Marriage' (Issue Paper, 2020) ('Interlinkages between Trafficking in Persons and Marriage'). This paper explores how some forms of marriage, including forced marriage, are connected to trafficking in persons.

5 Transforming Our World: The 2030 Agenda for Sustainable Development, GA Res 70/1, UN Doc A/Res/70/1 (21 October 2015, adopted 25 September 2015) annex ('Sustainable Development Goals') Goal 5.2.

6 The UN Committee on the Elimination of Discrimination against Women defines gender-based violence as 'violence which is directed against a woman because she is a woman or that affects women disproportionately' and specifically identifies forced marriage as a form of gender-based violence: Committee on the Elimination of Discrimination against Women, General Recommendation No 35 on Gender-based Violence against Women, Updating General Recommendation No 19, UN Doc CEDAW/C/ GC/35 (26 July 2017) 1 [1], 12 [29]. See also Division of International Protection Services, United Nations High Commissioner for Refugees, UNHCR Handbook for the Protection of Women and Girls (Handbook, January 2008) 194.

7 For example, the Convention on the Elimination of All Forms of Discrimination against Women, opened for signature 18 December 1979, 1249 UNTS 13 (entered into force 3 September 1981) ('CEDAW') acknowledges that forced marriage is a practice that occurs against a backdrop of pervasive inequality by requiring State parties to eliminate discrimination against women and ensure 'on a basis of equality of men and women: (a) The same right to enter into marriage; (b) The same right freely to choose a spouse and to enter into marriage only with their free and full consent': at art 16(1).

8 Megan Arthur et al, 'Child Marriage Laws around the World: Minimum Marriage Age, Legal Exceptions, and Gender Disparities' (2018) 39(1) Journal of Women, Politics and Policy 51, 66-7. Arthur et al found extensive gender discrimination in national marriage laws, with 122 countries allowing girls under 18 to marry either with or without parental consent, and 59 countries allowing girls to marry at a younger age than boys with parental consent.

9 Sundari Anitha, 'Understanding Economic Abuse through an Intersectional Lens: Financial Abuse, Control, and Exploitation of Women's Productive and Reproductive Labor' (2019) 25(15) Violence Against Women 1854, 1871; Sundari Anitha and Aisha Gill, 'Coercion, Consent and the Forced Marriage Debate in the UK' (2009) 17(2) Feminist Legal Studies 165, 165 ('Coercion, Consent and Forced Marriage').

10 International Covenant on Civil and Political Rights, opened for signature 16 December 1966, 999 UNTS 171 (entered into force 23 March 1976) art 23(3); International Covenant on Economic, Social and Cultural Rights, opened for signature 16 December 1966, 993 UNTS 3 (entered into force 3 January 1976) art 10(1). 
the union' and 'as a marriage in which one of the parties is not permitted to end or leave it'. ${ }^{11}$ It is this absence of consent that distinguishes a forced marriage from an arranged marriage, which is legal and occurs with the consent of both parties. However, this distinction may sometimes be difficult to discern in cases involving subtle forms of coercion exerted over a prolonged period of time; as Anitha and Gill explain, consent and coercion in relation to marriage is best understood not in binary terms, but as 'two ends of a continuum, between which lie degrees of social-cultural expectation, control, persuasion, pressure, threat and force'. ${ }^{12}$

In Australia, forced marriage has been recognised as a form of family violence ${ }^{13}$ and a manifestation of modern slavery. ${ }^{14}$ However, Australia's initial response to forced marriage evolved under the umbrella of Australia's National Action Plan

11 Committee on the Elimination of Discrimination against Women and Committee on the Rights of the Child, Joint General Recommendation No 31 of the Committee on the Elimination of Discrimination against Women/General Comment No 18 of the Committee on the Rights of the Child on Harmful Practices, UN Doc CEDAW/C/GC/31/CRC/C/GC/18 (14 November 2014) 7-8 [23]. See also 7 [20] observing forced marriage may manifest as child marriage.

12 Anitha and Gill, 'Coercion, Consent and Forced Marriage' (n 9) 165.

13 Department of Social Services (Cth), Fourth Action Plan: National Plan to Reduce Violence against Women and Their Children 2010-2022 (Action Plan, 2019) 29-30. In response to the recommendations of the Victorian Royal Commission into Family Violence, the Family Violence Protection Act 2008 (Vic) was amended to include two new examples of what constitutes 'family violence' for the purpose of the Act, being: 'using coercion, threats, physical abuse or emotional or psychological abuse to cause or attempt to cause a person to enter into a marriage'; and 'using coercion, threats, physical abuse or emotional or psychological abuse to demand or receive dowry, either before or after a marriage': Family Violence Protection Act 2008 (Vic) s 5. See also Intervention Orders (Prevention of Abuse) Act 2009 (SA) s 8(4) (oa). In New South Wales ('NSW'), the Modern Slavery Act 2018 (NSW), which is yet to commence, has provided for amendment of the definition of a 'personal violence offence' in section 4 of the Crimes (Domestic and Personal Violence) Act 2007 (NSW) to include child forced marriage: Modern Slavery Act 2018 (NSW) sch 5.3 item 1. In effect, this would incorporate child forced marriage into the section 11 definition of 'domestic violence offence' where the parties are in a domestic relationship. In March 2021, a Commonwealth parliamentary inquiry recommended that the 'Australian Government work with state and territory governments to adopt a uniform definition of family, domestic and sexual violence', which includes forced marriage: House of Representatives Standing Committee on Social Policy and Legal Affairs, Parliament of Australia, Inquiry into Family, Domestic and Sexual Violence (Report, March 2021) xxi [2.191] recommendation 1. It was recommended that this uniform definition encompass 'a broad range of violence, including but not limited to coercive control, reproductive coercion, economic abuse, and complex forms of violence, such as forced marriage, female genital mutilation/cutting and dowry abuse', and recognise the diversity of victim-survivors and the vulnerability of particular groups.

14 Section 4 of the Modern Slavery Act 2018 (Cth) defines 'modern slavery' as conduct that is criminalised under divisions 270 or 271 of the Criminal Code Act 1995 (Cth) sch 1 ('Criminal Code'), which captures the offences of slavery, forced labour, forced marriage and debt bondage, as well as trafficking in persons as defined in the Trafficking Protocol and 'the worst forms of child labour', whether or not such conduct occurred in Australia. This definition is broader than the definition of modern slavery included in the Modern Slavery Act 2015 (UK) which includes slavery, servitude, forced or compulsory labour and human trafficking. In the final report of the Parliamentary Inquiry into establishing a Modern Slavery Act in Australia ('the Inquiry'), the Joint Standing Committee acknowledged that there was 'no globally agreed definition of "modern slavery", and that the term is "increasingly being used by advocacy groups, international organisations and governments ... to refer to a wide range of exploitative crimes': Joint Standing Committee on Foreign Affairs, Defence and Trade, Parliament of Australia, Hidden in Plain Sight: An Inquiry into Establishing a Modern Slavery Act in Australia (Report, December 2017) [3.4]-[3.5] ('Hidden in Plain Sight'). The 2020 Trafficking in Persons Report acknowledged that the terms 'human trafficking', 'trafficking in persons' and 'modern slavery' are all 'interchangeable umbrella terms': United States of America Department of State, Trafficking in Persons Report 20th Edition (Report, June 2020) 3 ('2020 Trafficking in Persons Report'). Critics have pointed to the challenges of using a term that has 
to Combat Human Trafficking and Slavery and prioritised a punitive approach (criminalisation), over protective legislation (civil protection orders to protect those at risk of forced marriage). ${ }^{15}$ In 2013, a federal offence of forced marriage was introduced into the Criminal Code Act 1995 (Cth) schedule 1 ('Criminal Code') ${ }^{16}$ as part of reforms to expand the suite of slavery and human trafficking offences in divisions 270 and 271 of the Criminal Code 'to ensure that the broadest range of exploitative behaviour is captured and criminalised' ${ }^{17}$ Forced marriage was also identified as a "slavery-like practice" ${ }^{18}$ and a form of criminal 'exploitation" ${ }^{19}$ for the purposes of separate offences of trafficking in persons.

The question of how, and from which perspectives, to evaluate responses to forced marriage deserves attention. Official data about forced marriage focuses on interaction with the Commonwealth criminal justice system: to date, there have been no convictions for the offence of forced marriage and, while some parliamentary inquiries have touched upon Australia's response to forced marriage, ${ }^{20}$ there has been no official evaluation of the impact of interventions to address forced marriage. The only matter currently before the courts, which concerns a woman who was murdered by her husband after she was allegedly forced to marry him, ${ }^{21}$ is a tragic reminder of the critical importance of strategies to prevent forced marriages before they occur and to protect those at risk. Individuals who are identified as victims of 'modern slavery' by authorities may be able to access victim support under the government-funded Support for Trafficked People Program ('STPP'), administered by the Department of Social Services and delivered by the Australian Red Cross. ${ }^{22}$

no definition in international law and does not acknowledge the extent to which slavery has been present throughout history and is not a 'modern' problem: Hidden in Plain Sight (n 14) 43 [3.42]-[3.43].

15 A discussion paper canvassed criminal law reform and civil law as well as non-legislative measures: Commonwealth Attorney-General's Department, Criminal Justice Division, 'Forced and Servile Marriage' (Discussion Paper, 2010).

16 Crimes Legislation Amendment (Slavery, Slavery-like Conditions and People Trafficking) Act 2013 (Cth) sch 1 items 8, 12.

17 Explanatory Memorandum, Crimes Legislation Amendment (Slavery, Slavery-like Conditions and People Trafficking) Bill 2012 (Cth) 2.

18 A 'slavery-like offence' means an offence against any of the following provisions (a) section 270.5 (servitude offences); (b) section 270.6A (forced labour offences); (c) section 270.7 (deceptive recruiting for labour or services); (d) section 270.7B (forced marriages offences); (e) section 270.7C (debt bondage): Criminal Code 1995 (Cth) s 271.1A.

19 Ibid s 271.1A.

20 See, eg, Parliamentary Joint Committee on Law Enforcement, Parliament of Australia, An Inquiry into Human Trafficking, Slavery and Slavery-Like Practices (Report, July 2017) ch 5; Hidden in Plain Sight (n 14); House of Representatives Standing Committee on Social Policy and Legal Affairs, Parliament of Australia, Inquiry into Family, Domestic and Sexual Violence (Report, March 2021).

21 Angie Raphael, 'Man Pleads Guilty to Murdering Wife Who Police Say Became His Bride through an Arranged Marriage', The Australian (online, 25 February 2021) < https://www.theaustralian.com.au/ breaking-news/man-pleads-guilty-to-murdering-wife-who-police-say-became-his-bride-through-anarranged-marriage/news-story/d9c9bb19a065c356db20527ca3eecf16>. See also Australian Federal Police, 'Three Arrested after Alleged Forced Marriage of Shepparton Woman' (Media Release, 8 October 2020) <https://www.afp.gov.au/news-media/media-releases/three-arrested-after-alleged-forced-marriageshepparton-woman>.

22 All suspected victims referred to the Support for Trafficked People Program ('STPP') by the Australian Federal Police ('AFP') can access an initial 45 days of intensive support, and after this time, victims may access a further 45 days of support if they are willing to assist with an investigation or prosecution. Since 2018 , children or victims of forced marriage have been able to access up to 200 days of support: 'Support 
Access to this support is contingent upon being identified as a potential victim by law enforcement. ${ }^{23}$ Since the criminalisation of forced marriage, individuals identified by the Australian Federal Police ('AFP') as at risk of or subject to a forced marriage may be referred to the STPP. ${ }^{24}$ If a suspected victim does not hold a valid visa, the AFP can also support that person to obtain a temporary visa under the human trafficking visa framework. ${ }^{25}$ In cases involving adults, referrals will only be made with the consent of the individual at risk and there is limited publicly available information about what information about accessing assistance is given to individuals who decline to be referred to the STPP.

Forced marriage has been described as 'a process rather than an event', ${ }^{26}$ reflecting the fact that ' $[t]$ he abusive nature of a forced marriage does not begin and end on the day of the marriage ceremony' ${ }^{27}$ However, while a forced marriage results in further abuse, the Criminal Code focuses attention on the point of time that the marriage is entered into ${ }^{28}$ defining a forced marriage as a marriage where:

(a) either party to the marriage (the victim) entered into the marriage without freely and fully consenting:

(i) because of the use of coercion, threat or deception; or

(ii) because the victim was incapable of understanding the nature and effect of the marriage ceremony; or

(b) when the marriage was entered into, either party to the marriage (the victim) was under $16 .^{29}$

While this definition focuses on an event - the marriage - unpacking the term 'coercion' points to the challenges that can arise in identifying a person who is at

for Trafficked People Program', Australian Government Department of Social Services (Web Page, 23 December 2020) <https://www.dss.gov.au/women/programs-services/reducing-violence/anti-peopletrafficking-strategy/support-for-trafficked-people-program>.

23 'Interlinkages between Trafficking in Persons and Marriage' (n 4) xi (noting that many countries provide support services to victims of trafficking that may not be available for other types of crime).

24 See above $\mathrm{n} 22$ and accompanying text.

25 To access the STPP, victims who need to regularise their immigration status may be granted a bridging visa $\mathrm{F}$ under the Human Trafficking Visa Framework. Where a person makes a contribution to an AFP investigation and would be in danger if returned to their home country, the AFP can also initiate a process that can result in the grant of a permanent visa. Between 2016 and 2019, approximately 133 temporary visas and 24 permanent visas were granted to suspected victims of modern slavery: United States of America Department of State, Trafficking in Persons Report (Report, June 2019) 76; 2020 Trafficking in Persons Report (n 14) 83. Between 1 January 2004 and 30 June 2016, 483 temporary visas and 132 permanent visas were granted under the Human Trafficking Visa Framework: Hidden in Plain Sight (n 14) 153 .

26 Khatidja Chantler and Melanie McCarry, 'Forced Marriage, Coercive Control, and Conducive Contexts: The Experience of Women in Scotland' (2020) 26(1) Violence Against Women 89, 95.

27 Re K (Forced Marriage: Passport Order) [2020] EWCA Civ 190, [24].

28 Criminal Code 1995 (Cth) s 270.7B. A forced marriage involving a child is an aggravated offence: at s 270.8(1)(a). In 2019, the Criminal Code definition of forced marriage was amended to explicitly encompass all marriages involving children under the age of 16 . While previously there was a rebuttable presumption that children under the age of 16 did not consent to the marriage, it is now clear that there are no circumstances in which a child under the age of 16 can consent to marriage: Combatting Child Sexual Exploitation Legislation Amendment Act 2019 (Cth) sch 5 item 1, amending Criminal Code 1995 (Cth) s $270.7 \mathrm{~A}(1)(\mathrm{b})$.

29 Criminal Code 1995 (Cth) s 270.7A(1) (definition of 'forced marriage') (emphasis in original). 
risk of forced marriage. The coercion or threats that cause a non-consenting party to enter into a marriage can encompass conduct that began long before the marriage, and coercion is defined broadly to include force, duress, detention, 'psychological oppression', 'abuse of power', or 'taking advantage of a person's vulnerability'. ${ }^{30}$

Forced marriage is also recognised as a form of family violence, which can involve a spectrum of coercive and controlling behaviours, ${ }^{31}$ and coercion, in all its varied forms, is key to understanding forced marriage. While reports to the AFP have increased (see Figure 1), there are no reliable estimates of the prevalence of forced marriage and the problem is likely under-reported. ${ }^{32}$ As we discuss, people facing forced marriage may be unwilling to report their victimisation for a range of reasons, including concern about exposing family members to official investigation, fear of authorities or because they do not self-identify as victims..$^{33}$ Compounding these challenges: frontline responders may lack the capacity to identify cases of forced marriage or provide appropriate referrals to support services. ${ }^{34}$ Very few cases investigated by the AFP result in prosecutions, which may reflect - at least in part - the reluctance of victims to expose family members to prosecution, and the fact that most reports to the AFP concern circumstances where, because the marriage has not yet occurred, 'an offence against Australian law may not have been committed' ${ }^{35}$ One attempt to prosecute an offence of forced marriage, where

30 Ibid s 270.1A (definition of 'coercion'). The term 'threat' is also defined in section 270.1A of the Criminal Code as: '(a) a threat of coercion; or (b) a threat to cause a person's deportation or removal from Australia; or (c) a threat of any other detrimental action, unless there are reasonable grounds for the threat of that action in connection with the provision of labour or services by a person'. A threat can be made 'by any conduct, whether express or implied and whether conditional or unconditional'.

31 Australian Institute of Judicial Administration, 'Forced Marriage', National Domestic and Family Violence Bench Book (Bench Book, June 2020) <https://dfvbenchbook.aija.org.au/understandingdomestic-and-family-violence/forced-marriage/>.

32 For example, in 2012 and 2013, the National Children's and Youth Law Centre collected 91 web-based survey responses from government and non-government organisations. Within this small survey, 50 respondents 'had encountered child clients in or at risk of a forced marriage in the preceding 24 months, and these experiences were estimated to have involved an excess of 250 cases': Tina Jelenic and Matthew Keeley, End Child Marriage Australia: Research Report on the Forced Marriage of Children in Australia (Research Report, May 2013) 22. The Australian Muslim Women's Centre for Human Rights noted that crimes against women and child are often not reported by the victims to the police: Australian Muslim Women's Centre for Human Rights, Child and Forced Marriage: A Guide for Professionals Working with the Muslim Community (Report, 2019) 2. The Australian Institute of Criminology ('AIC') also estimated that 4 in 5 modern slavery victims in Australia, representing between 928 and 1,483 victims, are undetected: Samantha Lyneham, Christopher Dowling and Samantha Bricknell, Estimating the Dark Figure of Human Trafficking and Slavery Victimisation in Australia (Statistical Bulletin No 16, 15 February 2019) 6. The AIC did not make any estimates specific to forced marriage, but noted that forced marriage has now been included in 'both detected and estimated populations': at 3.

33 These observations are supported by this study as well as earlier studies: Samantha Lyneham and Samantha Bricknell, When Saying No Is Not An Option: Forced Marriage in Australia and New Zealand (Research Report No 11, 15 June 2018) 2, 61, 81. See also, in the context of the United States of America, Hanna Love et al, 'Navigating an Unclear Terrain: Challenges in Recognizing, Naming, and Accessing Services for "Forced Marriage"” (2019) 25(9) Violence Against Women 1138.

34 Royal Commission into Family Violence: Report and Recommendations (Final Report, March 2016) vol 5, 111 .

35 Emily Baker, 'Report Details Abuse of Forced Marriage Victims Living in Australia', Canberra Times (online, 1 July 2018) < https://www.canberratimes.com.au/national/act/report-details-abuse-of-forcedmarriage-victims-living-in-australia-20180628-p4zo8a.html>. See also Australian Federal Police, 
the accused was alleged to have forced an asylum seeker to marry his 15-yearold daughter, resulted in two hung juries. ${ }^{36}$ In another case, a man who married a 14-year-old girl pleaded guilty to other charges. ${ }^{37}$ But while convictions have been elusive, the AFP now receives more reports of forced marriage than any other type of human trafficking, slavery or slavery-like practice..$^{38}$

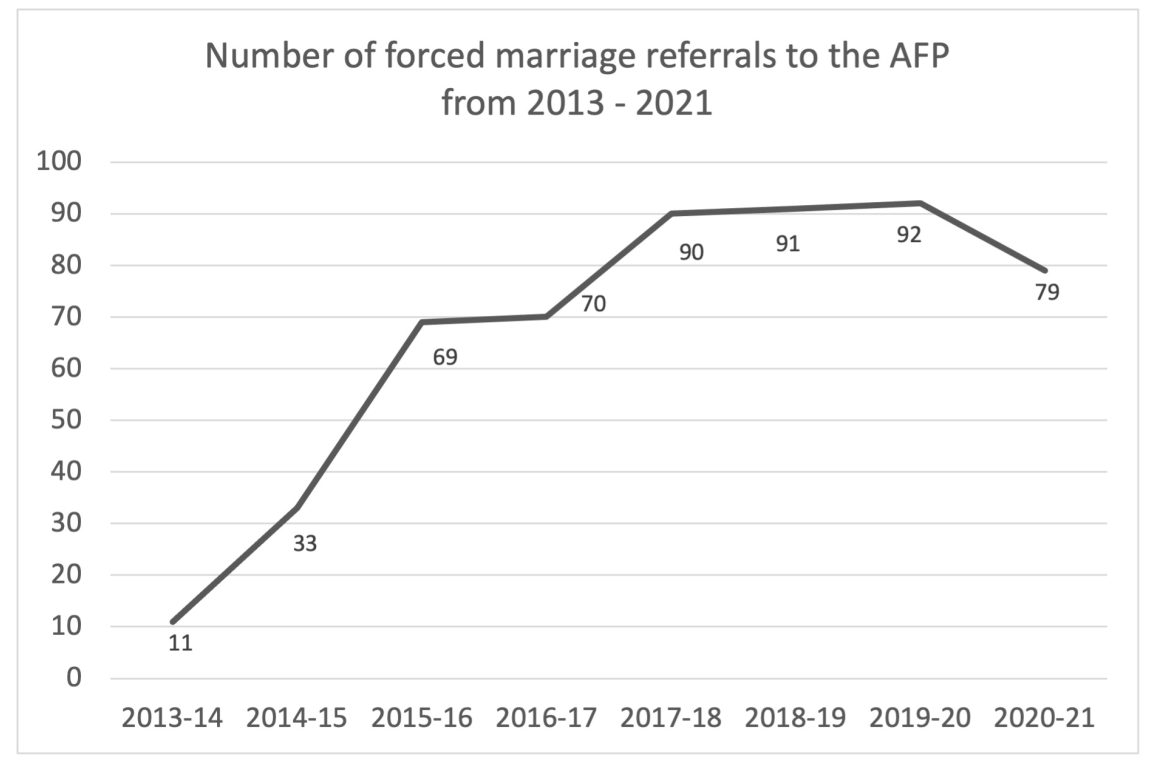

Figure 1 Forced Marriage Referrals to the Australian Federal Police ${ }^{39}$

Annual Report 2018-19 (Report, 11 October 2019) 35 (noting '[o]ften with human trafficking and forced marriage matters there is insufficient evidence for prosecution'). The AFP has highlighted the importance of disruption, deterrence, and supporting those who are at risk of forced marriage: Kelly Burke, 'Federal Police Launch Advertising Blitz at Sydney Airport on Forced Marriage', 7News (online, 15 October $2019)<$ https://7news.com.au/news/crime/federal-police-launch-advertising-blitz-at-sydney-airport-onforced-marriage-c-504265>.

36 Shannon Deery, 'Child Bride Accused Faces Yet Another Trial', Herald Sun (online, 26 March 2020) $<$ https:/www.heraldsun.com.au/truecrimeaustralia/police-courts/possible-third-trial-for-childbrideaccused-as-another-jury-struggles-to-reach-verdict/news-story/7946e61c7b06fdebe44cdf5ce 7492ef5>.

37 DPP v Shakir [2017] VCC 1374. The cleric who performed the marriage was also convicted of offences under the Marriage Act 1961 (Cth): Omerdic v Angland [2018] VSC 174. Leave to appeal against this judgment was refused: Omerdic v Angland [2018] VSCA 320. See also Tessa Akerman, 'Conviction Rate Remains Zero after "Forced” Marriage Charges Reduced', The Australian (online, 19 April 2017) <http:// www.theaustralian.com.au/news/nation/conviction-rate-remains-zero-after-forced-marriage-chargesreduced/news-story/76e19b11a1d3284b0d90cfecef04fa26>.

38 Australian Federal Police, Annual Report 2017-18 (Report, 5 October 2018) 39. See also Hidden in Plain Sight (n 14) 59, which outlines government data on the number of referrals to the AFP of human trafficking and slavery offences between 2013 and 2017, disaggregated by offence type.

39 The data in Figure 1 is drawn from the following sources: Australian Federal Police, Annual Report 2016-17 (Report, 15 September 2017) 52; Australian Federal Police, 'Forced Marriage Awareness Campaign Launched at Australia's Busiest Airport' (Media Release, 15 October 2019); Australian Federal Police, 'Stop Human Trafficking Happening in Plain Sight' (Media Release, 30 July 2020); Hidden in 
Most cases reported to the AFP involve female victims, often under 18 years of age ${ }^{40}$ facing a forced marriage offshore. The perpetrators are generally family members. ${ }^{41}$ Providing intensive support to victims of forced marriage is now a significant component of the work of the STPP, a program that, in its initial incarnation, was chiefly responsible for supporting women who had experienced slavery or servitude in the sex industry. Between 2009 and 2019, the STPP supported 535 people, most of whom $(83 \%)$ were women, ${ }^{42}$ and a quarter of whom $(25 \%)$ were identified as victims of forced marriage. ${ }^{43}$ Forced marriage disproportionately affects women and girls, ${ }^{44}$ and in the last five years, there has been a significant increase in the number of children referred to the STPP $(n=60)$, most of whom $(n=47)$ were identified as at risk of, or subject to, forced marriage. ${ }^{45}$ A recent study suggests the impact of the COVID-19 pandemic may help explain the drop in reports of forced marriage in 2020-21. ${ }^{46}$

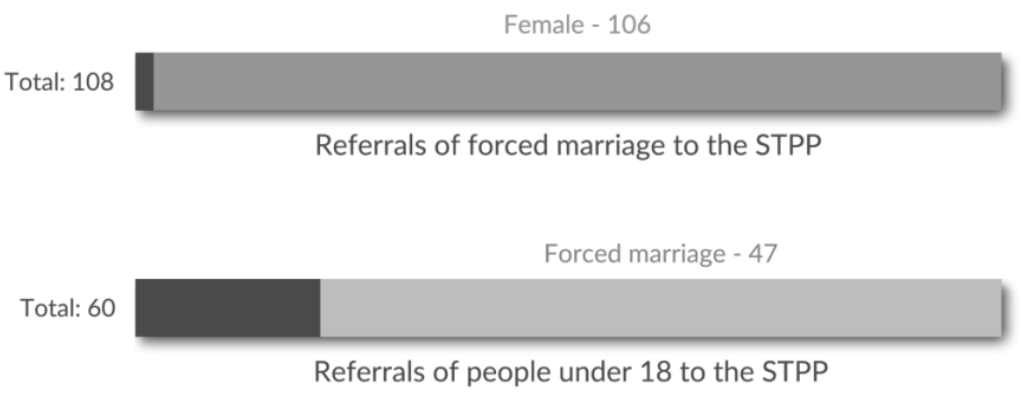

Source: Australian Red Cross, Support for Trafficked People Program Data Snapshot: 2009 to 2019 (Report, November 2019 ) 6.

Figure 2 Referrals of Forced Marriage to the STPP

Plain Sight (n 14) 59; Australian Federal Police, 'Victims' Voices Lead the Way on World Day against Trafficking in Persons' (Media Release, 30 July 2021).

40 Australian Federal Police, 'Stop Human Trafficking Happening in Plain Sight' (Media Release, 30 July 2020) (estimating that in 2019-20, 70\% of cases involving a forced marriage involved a marriage offshore and 51\% involved victims under 18 years of age); Australian Red Cross, Support for Trafficked People Program Data Snapshot: 2009 to 2019 (Report, 24 November 2019) 3 ('STPP Data Snapshot: 2009 to 2019').

41 Lyneham and Bricknell (n 33) 37, 81.

42 STPP Data Snapshot: 2009 to 2019 (n 40) 3. Of the women on the STPP, 38\% have been suspected victims of sexual exploitation, $30 \%$ suspected victims of forced marriage and $25 \%$ suspected victims of labour exploitation.

43 Ibid 4. This includes people at risk of forced marriage and people who have experienced forced marriage. No cases of forced marriage were referred to the STPP before 2014.

44 Ibid 6 (see Figure 2).

45 Ibid 4.

46 See generally Nerida Chazal and Kyla Raby, 'The Impact of Covid-19 on the Identification of Victims of Modern Slavery and Their Access to Support Services in Australia' (2021) 6(2) Journal of Modern Slavery 30, 38 (noting the impact of service closures and the diversion of police resources on reporting of forced marriage). 
The only way to access the STPP is through a referral from the AFP as the AFP holds the exclusive power to identify and refer suspected victims of forced marriage to the STPP. ${ }^{47}$ Between 8 March 2013, when forced marriage offences entered into force, and 30 June 2021, the AFP received 535 reports of forced marriage, and, as at November 2019, ${ }^{48}$ the AFP had referred 108 people at risk of forced marriage to the STPP. There is significant attrition between the number of reports made to the AFP and the number of referrals the AFP makes to the STPP (compare Figures 1 and 2): over time, less than 1 in 4 reports to the AFP result in a referral to the STPP, raising concerns that, even where people facing forced marriage have contact with the authorities, they may be unable to access support. Anecdotally, this attrition may reflect the fact that, in some cases, the AFP may assess the person is not in, or at risk of, a forced marriage, while in other cases, a person may not consent to the AFP referring their case to the STPP (it is not known how many reports to the AFP are made by third parties), or the referral cannot be made as the victim is offshore. However, the referral process is opaque: STPP case workers themselves are unclear about how the AFP assesses forced marriage referrals for the STPP. ${ }^{49}$ Without data detailing the outcomes of reports to the AFP or a more transparent referral mechanism, the causes of this attrition will remain unclear.

\section{B Criticisms of Australia's Response to Forced Marriage}

Australia's response to forced marriage has been criticised for reproducing the flaws in its response to human trafficking and slavery: the emphasis on criminal justice means punitive responses have been prioritised over primary prevention initiatives and protective legislation, while the root causes of forced marriage are left unexplored and unaddressed. ${ }^{50}$ The death of 21-year-old Ruqia Haidari, who alleged she was being forced to marry when she met with the AFP in August $2019^{51}$ and was murdered by her husband in January $2020,{ }^{52}$ underscores the need to better understand how people can become trapped in a forced marriage so as to improve pathways to support and assistance. One consequence of responding to forced

47 National Roundtable on Human Trafficking and Slavery, Guidelines for NGOs: Working with Trafficked People (Guidelines 3rd ed, 2015) 13; Australian Government, Submission No 89 to Joint Standing Committee on Foreign Affairs, Defence and Trade, Parliament of Australia, Inquiry into Establishing a Modern Slavery Act in Australia (April 2017) 12.

48 STPP Data Snapshot: 2009 to 2019 (n 40) 4; see Figure 1.

49 An evaluation of the support program for people who are facing forced marriage noted that a better understanding of the AFP's assessment process would benefit STPP staff as well as ongoing efforts to expand referral pathways into the STPP: Kathleen Stacey and Sheryl Boniface, Australian Red Cross Forced Marriage Stream Trial Evaluation (Final Evaluation Report, August 2019) 19.

50 Eve Lester, Speaking Up, Speaking Out, Speaking With: Advocacy Challenges for Civil Society's Work with Migrants in Vulnerable Situations (Report, April 2020) 18; Laura Vidal, 'Opportunities to Respond to Forced Marriage within Australia's Domestic and Family Violence Framework' (Issues Paper, Good Shepherd Australia New Zealand, 2019) 9.

51 Australian Federal Police, 'Three Arrested after Alleged Forced Marriage of Shepparton Woman' (Media Release, 8 October 2020) <https://www.afp.gov.au/news-media/media-releases/three-arrested-afteralleged-forced-marriage-shepparton-woman>.

52 Joanna Menagh, 'Mohammad Ali Halimi Sentenced to Life Imprisonment for Murdering 21-year-old Ruqia Haidari', $A B C$ News (online, 2 August 2021) < https:/www.abc.net.au/news/2021-08-02/man-whokilled-forced-marriage-bride-jailed/100342086>. 
marriage under the amorphous banner of modern slavery is that opportunities have been missed to integrate responses to forced marriage within frameworks to address family violence, ${ }^{53}$ while access to dedicated victim support is conditional on contact with the AFP. ${ }^{54}$ Concerns have also been raised that locating forced marriage within responses to human trafficking risks stigmatising certain migrant communities by racialising and exoticising 'such manifestations of abuse as unique to transnational marriages ... and as unconnected to generic forms of domestic violence'. ${ }^{55}$ Anitha and Gill, among others, advocate for the use of an intersectional lens and 'continuum-thinking' to understand the connections between forced marriage and more 'generic' forms of domestic violence. ${ }^{56}$

While it is beyond the scope of this article to examine debates about whether responses to forced marriage should be located within a modern slavery or family violence framework or whether there is scope for a multifaceted approach, currently neither framework is adequately equipped to respond to the protection needs of people facing forced marriage, particularly in cases involving children. ${ }^{57}$ In an acknowledgment that victims 'are often under 18 and require longer term assistance' and that the 'requirement to cooperate with a criminal justice process in order to access support was preventing many victims from getting help' ${ }^{58}$ in 2019, changes were made to the STPP to enable victims of forced marriage to access up to 200 days of support without being required to contribute to a criminal investigation or prosecution. ${ }^{59}$ However, the precondition for access to the STPP - a referral from the AFP - remains unchanged and, in this way, the problem of conditionality persists. The human trafficking visa framework is also still tied to cooperation with criminal justice investigations. ${ }^{60}$

The civil remedies that exist under Commonwealth, state and territory laws that may provide protection to people in, or at risk of, forced marriage were not designed to respond to cases of forced marriage: they provide different levels

53 Heli Askola, 'Responding to Vulnerability? Forced Marriage and the Law' (2018) 41(3) University of New South Wales Law Journal 977, 979, 981-2; Helen Sowey, 'From an Emic Perspective: Exploring Consent in Forced Marriage Law' (2018) 51(2) Australian and New Zealand Journal of Criminology 258; Frances Simmons and Jennifer Burn, 'Without Consent: Forced Marriage in Australia' (2013) 36(3) Melbourne University Law Review 970; Lyneham and Bricknell (n 33); Lester (n 50) 18; Vidal (n 50) 5, 9-10.

54 Multiple inquiries into human trafficking have recommended that access to victim support should not be conditional on contact or cooperation with law enforcement: see, eg, Hidden in Plain Sight (n 14) xl [6.79].

55 Anitha (n 9) 1871.

56 Anitha and Gill, 'Coercion, Consent and Forced Marriage' (n 9) 165. See also Chloe Patton, 'Racialising Domestic Violence: Islamophobia and the Australian Forced Marriage Debate' (2018) 60(2) Race and Class 21.

57 Lyneham and Bricknell (n 33) 94 (noting the role of child protection agencies requires further attention); Aisha K Gill, Pamela Cox and Ruth Weir, 'Shaping Priority Services for UK Victims of Honour-Based Violence/Abuse, Forced Marriage, and Female Genital Mutilation’ (2018) 57(4) Howard Journal 576.

58 Dan Tehan, 'Greater Access to Support for Victims of Modern Slavery' (Media Release, Department of Social Services, 15 February 2018) <https://formerministers.dss.gov.au/17984/greater-access-to-supportfor-victims-of-modern-slavery/>.

59 Ibid. These changes were made after a one-year STPP trial which allowed forced marriage survivors to access longer-term support beyond the initial 45-day period without needing to participate in the criminal justice process: Stacey and Boniface (n 49) 3-4.

60 Migration Regulations 1994 (Cth) reg 2.07AK. For a discussion of the negative impact of uncertain immigration status on forced marriage victims, see Stacey and Boniface (n 49) 18. 
of protection to children and vulnerable young adults, and are rarely used to protect people facing forced marriage. Some cases of forced marriage can have a transnational element, and there have been a small number of cases in which a forced marriage, or the threat of such a marriage, triggered requests for orders under the Family Law Act 1975 (Cth) ('Family Law Act') for protection orders to prevent child permanent residents or Australian citizens from being taken out of Australia by family members. ${ }^{61}$ However, stakeholders have raised concerns ${ }^{62}$ that orders available under the Family Law Act do not protect adults who are at risk of being forced to marry overseas. ${ }^{63}$

A person in a forced marriage may apply to nullify the marriage under the Marriage Act 1961 (Cth) ${ }^{64}$ but this relief is only available after a forced marriage has taken place. Anecdotally, people facing forced marriage may seek protection orders under family violence legislation, ${ }^{65}$ however such orders were not designed to respond to forced marriage and there is a lack of data about the experiences of victims of forced marriage accessing domestic and family violence prevention orders. ${ }^{66}$

The limitations of existing civil remedies were tacitly acknowledged in 2018, when the Australian government announced it was developing a proposal for a Commonwealth Forced Marriage Protection Order ('FMPO') Scheme, ${ }^{67}$ similar to

61 Kandal v Khyatt (2010) 43 Fam LR 344; Department of Human Services v Brouker (2010) 44 Fam LR 486; Madley v Madley [2011] FMCAfam 1007; Anthony v Kellett [2016] FCCA 3368.

62 Anti-Slavery Australia, Submission No 9 to Joint Committee on Law Enforcement, Parliament of Australia, Inquiry into Human Trafficking (2016) 30 ('ASA Submission No 9'); Salvation Army, Submission No 14 to Joint Committee on Law Enforcement, Parliament of Australia, Inquiry into Human Trafficking (February 2016) 27 ('Salvation Army Submission No 14'); Australian Human Rights Commission, Submission No 23 to Joint Committee on Law Enforcement, Parliament of Australia, Inquiry into Human Trafficking (4 March 2016) 10 ('AHRC Submission No 23').

63 Family Law Act 1975 (Cth) pt VII. The preventative measures available for those at risk of forced marriages are orders and injunctions under the Family Law Act 1975 (Cth), which are only available in cases involving children: at pt VII divs 5-6, 8-9. Parenting orders can deal with various aspects of parenting including, 'any aspect of the care, welfare or development of the child or any other aspect of parental responsibility': at s 64B. Courts have the power to make certain other orders which protect children from forced marriage, such as injunctions preventing the removal or harassment of the child, and orders for the delivery of travel documents to the court: at ss $67 \mathrm{ZD}, 68 \mathrm{~B}$. In making a parenting order, the court must have regard to the child's best interest as a paramount consideration: at s 60CA. Parenting orders only prohibit the removal of children from Australia if they are removed without the consent of each person in whose favour the parenting order was made: at s $65 \mathrm{Y}$.

64 Kreet v Sampir (2011) 44 Fam L R 405; Nagri v Chapal [2012] FamCA 464; Radtke v Pagano [2016] FamCA 784; Sarvari v Atapati [2017] FamCA 928; Sikander v Vashti [2018] FamCAFC 111; Chirag $v$ Kanelka [2018] FAMCA 476. These cases have been dealt with under the Marriage Act 1961 (Cth) ('Marriage Act') which provides that a marriage will be found to be void or will not be recognised in Australia if the consent of either of the parties was not real because it was obtained by duress or fraud; a party was mistaken as to the identity of the other party or as to the nature of the ceremony performed; a party did not understand the nature and effect of the marriage ceremony; or either party was not of marriageable age, which in Australia is 18, although there can be exceptions in cases involving a party who is 16 or 17 years of age: Marriage Act ss 23(1)(d)-(e), 23B, 88C, 88D.

65 Magdalena McGuire, The Right to Refuse: Examining Forced Marriage in Australia (Report, April 2014) 74.

66 RMIT University and The Salvation Army Freedom Partnership, Without Choice: Examining Forced Marriage in Australia (Report, May 2018) 22 ('Without Choice Report').

67 Alex Hawke, 'Strengthening Australia's Response to Forced Marriage' (Press Release, 15 June 2018). The proposal to introduce a scheme of Forced Marriage Protection Orders ('FMPO') has attracted 
the scheme of civil remedies available in the United Kingdom ('UK'). ${ }^{68}$ At the time of writing, details of the proposed scheme were not public, however the National Action Plan to Combat Modern Slavery 2020-25 acknowledges the need to 'build on existing support for individuals in or at risk of forced marriage by developing a model for enhanced civil protections and remedies' ${ }^{69}$ In the UK, civil remedies have been far more frequently pursued than prosecutions; for example, there have been three convictions of the criminal offence of forced marriage following the introduction of this offence in 2014, ${ }^{70}$ and 1,066 FMPOs issued from January 2018 to June 2020. ${ }^{71}$ Applications for FMPOs can be made by a third party without the leave of the court' ${ }^{2}$ and have been described as 'hugely important in protecting [people at risk] and preventing forced marriage because the orders can be more finely tuned to fit an individual's circumstances and needs'. ${ }^{73}$ However, while there is still limited analysis of the effectiveness of FMPOs,${ }^{74}$ a recent study highlights the difficulties that arise when 'the onus [is] on vulnerable victims to provide proof of coercion instead of on perpetrators to provide proof of consent' and recommends judicial training to improve 'understanding of the range of coercive pressures in a family context' as well as greater witness support. ${ }^{75}$ As we discuss in Part IV, the utility of such a scheme in the Australian context will depend on its design and implementation, particularly as the experience in the UK indicates that victims

bipartisan support. It was also welcomed by some stakeholders. See, eg, ASA Submission No 9 (n 62) 29-30; Salvation Army Submission No 14 (n 62); AHRC Submission No 23 (n 62) 10; The Salvation Army, Supplementary Submission No 25.1 to Joint Committee on Law Enforcement, Parliament of Australia, Inquiry into Human Trafficking (January 2017) 6.

68 Forced Marriage (Civil Protection) Act 2007 (UK).

69 Australian Government, National Action Plan to Combat Modern Slavery 2020-25 (Action Plan, 9 December 2020) 26.

70 Crown Prosecution Service, Violence Against Women and Girls Report 2018-19 (Report, 12 September 2019) 20; John Bingham, 'First Ever Forced Marriage Conviction in UK', The Telegraph (online, 10 June 2015) <https://www.telegraph.co.uk/news/uknews/crime/11665908/First-ever-forced-marriageconviction-in-UK.html>.

71 Between January 2019 and June 2020, 742 orders were made: UK Ministry of Justice, Family Court Statistics Quarterly, England and Wales, October to December 2019 including 2019 Annual Trends (Report, 26 March 2020) 15; UK Ministry of Justice, Family Court Statistics Quarterly, England and Wales, January to March 2020 (Report, 25 June 2020) 13; UK Ministry of Justice, Family Court Statistics Quarterly, England and Wales, April to June 2020 (Report, 24 September 2020) 14. In 2018, 324 orders were made: UK Ministry of Justice, Family Court Statistics Quarterly, England and Wales, Annual 2018 including October to December 2018 (Report, 28 March 2019) 11.

72 Forced Marriage (Civil Protection) Act 2007 (UK) s 63C(2)(b). Most applications are made by local authorities. The Lord Chancellor made the Family Law Act 1996 (Forced Marriage) (Relevant Third Party) Order 2009 (UK) which established that a local authority is specified as a relevant third party for the purposes of applying for an FMPO, and specifies what types of council constitute a 'local authority'.

73 Re K (Forced Marriage: Passport Order) [2020] EWCA Civ 190, [28] (citing the submissions of the Southall Black Sisters).

74 Kyja Noack-Lundberg, Aisha K Gill and Sundari Anitha, 'Understanding Forced Marriage Protection Orders in the UK' (2021) 43(4) Journal of Social Welfare and Family Law (forthcoming). Ibid. 
may be reluctant to initiate civil proceedings against family members ${ }^{76}$ and there is still generally a low understanding of forced marriage as a process. ${ }^{77}$

Legal responses to forced marriage can only ever be one element of a multifaceted approach to forced marriage: ${ }^{78}$ social responses - primary prevention initiatives that focus on changing attitudes towards decision-making around marriage and gender roles, as well as safe housing for those at risk - are vital, as is education about legal rights and remedies. Research with communities affected by forced marriage ${ }^{79}$ has criticised the prevailing focus on criminal justice and recommended investing in strategies designed at a community level to educate and empower young people, parents and religious leaders; enhancing collaboration between community and service providers to improve frontline responses to young people affected by forced marriage; and engaging with the families of young people. ${ }^{80}$ But despite calls to develop community-led prevention and protection initiatives, ${ }^{81}$ until recently there has only been short-term, limited investment in community engagement and education programs. ${ }^{82}$

76 Gill, Cox and Weir (n 57) 586-8.

77 Iris Haenen, Force \& Marriage: The Criminalisation of Forced Marriage in Dutch, English and International Criminal Law (Cambridge University Press, 2014) 250. See also Gill, Cox and Weir (n 57) 587-8; Noack-Lundberg, Gill and Anitha (n 74); Khatidja Chantler et al, Understanding Forced Marriage in Scotland (Report, 30 January 2017) 37. Other problems identified with the implementation of UK FMPOs include lack of understanding and awareness of the orders, inconsistent approaches and lack of engagement from key institutions, the minimisation by courts of the violence experienced due to 'cultural framing', higher evidential thresholds and a tendency for legal practitioners to focus on forced marriage as an event rather than a process.

78 Aisha K Gill and Sundari Anitha, 'Forced Marriage Legislation in the UK: A Critique' in Aisha K Gill and Sundari Anitha (eds), Forced Marriage: Introducing a Social Justice and Human Rights Perspective (Zed Books, 2011) 137, 143-6 ('Forced Marriage Legislation in the UK'). See also Aisha Gill and Sundari Anitha, 'The Illusion of Protection? An Analysis of Forced Marriage Legislation and Policy in the UK' (2009) 31(3) Journal of Social Welfare and Family Law 257, 262-4; Helena Zeweri and Sara Shinkfield, 'Centring Migrant Community Voices in Forced Marriage Prevention Social Policy: A Proposed Reframing' (2021) Australian Journal of Social Issues (advance) 7.

79 Australian Red Cross, Forced Marriage: Community Voices, Stories and Strategies (Report, May 2019) 5,52 . The project consisted of eight focus group discussions held with 89 people ( 30 men and 59 women) who were from four communities - Afghan, Pakistani, Rohingya and Sri Lankan/South Indian Tamil speakers - and invited by Red Cross community liaisons to participate in focus group discussions: at 14. One focus group discussion was with religious leaders, while other group discussions focused on identifying the factors that make relationships strong, healthy and respectful, that lead to relationship breakdown, and that may contribute to a family forcing a marriage: at 14-15. In the context of the United Kingdom ('UK'), see also Geetanjali Gangoli, Lis Bates and Marianne Hester, 'What Does Justice Mean to Black and Minority Ethnic (BME) Victims/Survivors of Gender-based Violence?' (2020) 46(15) Journal of Ethnic and Migration Studies 3119.

80 Australian Red Cross, Forced Marriage: Community Voices, Stories and Strategies (Report, May 2019) 9-12.

81 Askola (n 53) 979, 981-2; Lyneham and Bricknell (n 33); Vidal (n 50) 10-13; Without Choice Report (n 66); Sowey (n 53); Georgia Prattis and Joumanah El Matrah, Australian Muslim Women's Centre for Human Rights, Marrying Young: An Exploratory Study of Young Muslim Women's Decision-Making around Early Marriage (Report, 2017) 2; Simmons and Burn (n 53).

82 In July 2019, the Australian government announced almost AUD400,000 for non-governmental organisations ('NGOs') to implement a community prevention program for human trafficking, which focused on forced marriage and forced labour that year: 2020 Trafficking in Persons Report (n 14) 83. Prior to that, in 2014, the government granted over AUD485,000 to three NGOs to develop forced 
The rhetorical commitment in official policies to a victim-centred, and more recently survivor-informed, response to forced marriage ${ }^{83}$ has not yet been matched by programs that aim to engage with survivors about their needs ${ }^{84}$ or the impact of existing laws and policies. Existing responses are hampered by a lack of interagency coordination, especially between federal agencies responsible for the Commonwealth response to forced marriage and state and territory agencies with responsibilities in relation to family violence and child protection. ${ }^{85}$ While there is a need for multi-agency guidance on how different agencies should respond to forced marriage collaboratively ${ }^{86}$ including specific protocol for cases involving children, such guidance does not yet exist. ${ }^{87}$ There is no mechanism for oversight of the referral process to the STPP, and recommendations to invest in systematic collection of data on forced marriage have not been implemented. ${ }^{88}$

marriage-related outreach, education and awareness-raising projects over three years: Joint Committee on Law Enforcement, Parliament of Australia, An Inquiry into Human Trafficking, Slavery and Slaverylike Practices (Report, 18 July 2017) 78 [5.27]. The Joint Committee raised concerns about the lack of ongoing funding for community engagement programs focused on forced marriage: at 81 [5.37]. In August 2021, the Assistant Minister for Customs, Community Safety and Multicultural Affairs, the Hon Jason Wood MP, announced that the Australian Government had awarded more than AUD1.67 million to seven organisations under the National Action Plan to Combat Modern Slavery 2020-25 Grant Program for a range of projects that dealt with forced marriage including 'a trial to build a tailored family dispute and conflict resolution model that is responsive to specific needs of individuals facing forced marriage': Jason Wood, 'Modern Slavery Grant Funding Provided to a Record Number of Organisations' (Media Release, 9 August 2021) <https://minister.homeaffairs.gov.au/jasonwood/Pages/modern-slaverygrant-funding-provided-to-a-record-number-of-organisations.aspx?utm_source=miragenews\&utm medium=miragenews\&utm_campaign $=$ news $>$.

83 One of the principles underpinning the National Action Plan to Combat Modern Slavery 2020-25 is '[ensuring] the voices of victims and survivors, particularly women and children, inform our responses to modern slavery': Australian Government, National Action Plan to Combat Modern Slavery 2020-25 (n 69). The 2020-25 National Action Plan's strategic priorities include partnering with victims and survivors and the development of a Victim and Survivor Engagement and Empowerment Strategy: at 28. One of the 'core principles' underpinning the previous National Action Plan to Combat Human Trafficking and Slavery 2015-19 is the provision of 'holistic and victim-centred support to trafficked people': Australian Government, National Action Plan to Combat Human Trafficking and Slavery 2015-19 (Action Plan, 1 December 2014) 18. The 2015-19 National Action Plan also emphasises that the rights and needs of trafficked people should be the 'overarching consideration' informing each pillar of Australia's strategy to combat human trafficking and slavery: at 22.

84 Without Choice Report (n 66) 26.

85 Ibid 25; Lyneham and Bricknell (n 33) 93.

86 Lyneham and Bricknell (n 33) 87, 93.

87 Action item 24 of the National Action Plan to Combat Modern Slavery 2020-25 for Australia commits to implementing a Protocol for the treatment of children suspected as victims of human trafficking, slavery or slavery-like practices, which would assumedly include child victims of forced marriage: Australian Government, National Action Plan to Combat Modern Slavery 2020-25 (n 69) 27. This protocol is not yet publicly available and its scope and application to cases of forced marriage is unknown.

88 Committee on the Elimination of Discrimination against Women, Concluding Observations on the Eighth Periodic Report of Australia, $1602^{\text {nd }}$ and $1603^{\text {rd }} \mathrm{mtg}$, UN Doc CEDAW/C/AUS/CO/8 (25 July 2018) [25]-[26]. 


\section{SURVIVOR EXPERIENCES AND INSIGHTS}

\section{A Research Objectives and Methodology}

This study sought to learn from people with lived experience of forced marriage, paying particular attention to their reflections on legal responses to forced marriage. We undertook eight in-depth semi-structured interviews with people who identified that they had experienced forced marriage or been threatened with forced marriage in Australia ${ }^{89}$ With the consent of the interviewees, these interviews, which were between one and two hours in length, were recorded and then transcribed for data analysis. Seven of the eight interviewees were women. The interviewees were all adults and were no longer in, or at risk of, a forced marriage. Three participants identified that they were children when they were first threatened with forced marriage.

The size of the study $(\mathrm{n}=8)$ reflects the difficulties of recruiting research participants from hidden populations ${ }^{90}$ and is similar in size to earlier studies in Australia $^{91}$ and other jurisdictions. ${ }^{92}$ While this is not a quantitative study and does not provide insights into the prevalence of forced marriage, the study provides unique insights into the limitations of legal responses and draws attention to the diverse experiences of forced marriage. As one interviewee explained:

No two stories are going to be the same and it's not a simple sort of black and white type issue ... there are a lot of complex emotions involved and the complexities of different cultures, different societal norms, community norms ...

The data was analysed using a thematic analysis to identify common themes as well as differences within the data set. ${ }^{94}$ In this article, we focus on five

89 This research was conducted in accordance with the terms of institutional ethics approval [ETH193954] from the University of Technology Sydney Human Research Ethics Committee. Interviews were conducted confidentially and completed before the COVID-19 pandemic. All the participants in the study were adults (ethics approval was not sought to conduct interviews with children) and interviews occurred with the informed consent of participants. Participants were informed about the opportunity to participate in the study by the Australian Red Cross and other specialist NGOs who acted as referring organisations by distributing information about the study to potential participants.

90 See, eg, discussion in Chantler and McCarry (n 26) 101. See also Chantler et al (n 77) 12.

91 Lyneham and Bricknell (n 33) 9. See also Without Choice Report (n 66), drawing on four survivor surveys and nine practitioner interviews, and Sowey (n 53), noting the lack of research that directly engages with forced marriage in the Australian context.

92 Chantler and McCarry (n 26) 92; Carolina Villacampa, 'Forced Marriage as a Lived Experience: Victims' Voices' (2020) 26(3) International Review of Victimology 344; Love et al (n 33).

93 Interviewee 2.

94 Virginia Braun and Victoria Clarke, 'Using Thematic Analysis in Psychology' (2006) 3(2) Qualitative Research in Psychology 77, 97. Participants were asked open questions in semi-structured interviews. Questions invited participants to reflect upon their experiences of help-seeking and their views and perspectives on Australia's response to forced marriage. After the data was obtained, the researchers familiarised themselves with the interview transcripts in order to generate codes and search for and identify themes within the data, before reviewing and defining these themes. The interview data is affected by selective bias: interviews were conducted with adults who were able to avoid or exit a situation of forced marriage and therefore does not capture the experience of those people for whom forced marriage became a reality that they could not escape. The researchers also did not seek to engage with people who were still in a situation of forced marriage, people who were under 18, or people who were currently assisting active police investigations were excluded. While the limitations of the data are 


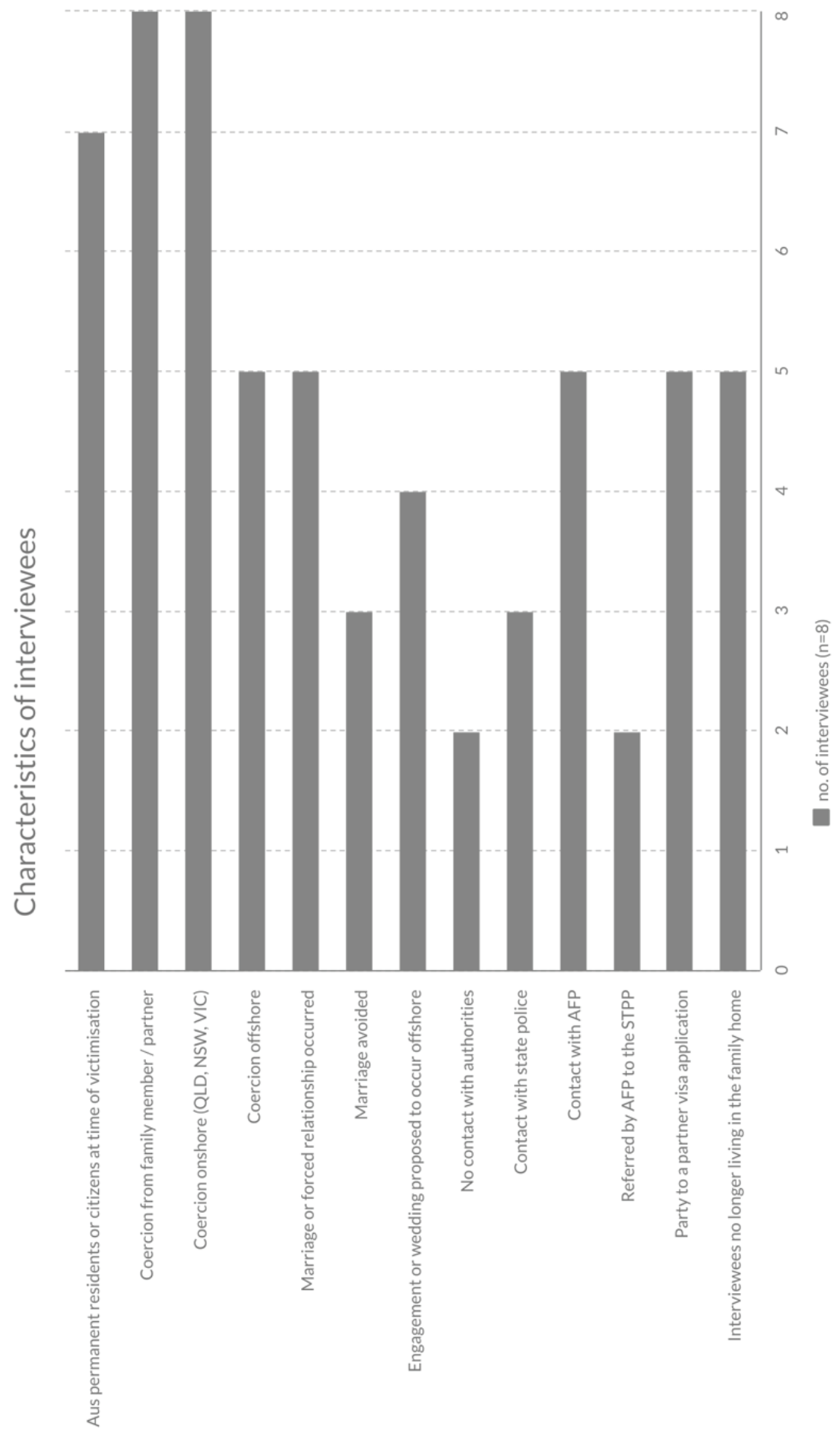

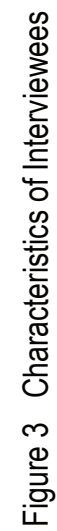


themes: the cumulative impact of experiences of coercion and control; survivors' understanding of the terms 'forced marriage' and 'family violence'; resistance in the face of obstacles (experiences of help-seeking); perspectives on seeking justice; and survivors' role in the design, implementation and evaluation of responses to forced marriage.

Participants in this study had diverse backgrounds: interviewees' families originated from South Asia, East Asia, the Middle East and the Pacific; six interviewees were born overseas, two were born in Australia. In most cases $(n=7)$, participants were threatened with, or experienced, forced marriage after the introduction of the offence of forced marriage in 2013. In two cases, the interviewees were able to avoid the threat of forced marriage. ${ }^{95}$ There were no criminal charges made in relation to any of the matters involving the interviewees.

\section{B Cumulative Impact of Experiences of Coercion and Control}

All of the participants described experiencing increasing psychological coercion over a sustained period of time, either from members of their immediate or extended family or, in one case, from the person with whom they were forced to have a relationship. Only two of the interviewees experienced physical violence before the marriage, although a greater number of interviewees $(n=4)$ described feeling at risk of physical violence from family members or their prospective spouse. The majority of interviewees $(n=7)$ described facing intense family pressure to marry to avoid bringing shame upon their family, and some were concerned that taking action to avoid the forced marriage might place other family members in danger. Family dynamics were complex: in some instances, interviewees identified some family members were responsible for controlling, coercive and sometimes physically violent behaviour, while others were allies or sympathetic to their circumstances.

Forced marriages are often arranged by family members in families and communities that are socially conservative with a strong sense of tradition, ${ }^{96}$ and this was consistent with the experiences of seven of the eight interviewees in this study. In line with the findings of previous studies, ${ }^{97}$ participants reported that family members sought to control behaviour and sexuality that was perceived as transgressive and did not comply with socio-cultural expectations of gender roles and marriage, and faced community pressure to maintain their 'reputation' and fulfil commitments, sometimes made years earlier, to family members. In five cases, these motivations were enmeshed with pressure to facilitate the migration of the proposed spouse to Australia via the partner migration scheme. ${ }^{98}$

acknowledged, it nevertheless provides rich insights into the lived experience of people who have avoided or exited a forced marriage.

95 This figure includes a case where the victim of forced marriage was unsure whether she was married under the law of another country.

96 Lyneham and Bricknell (n 33) vii.

97 Ibid. See also Australian Red Cross, Forced Marriage: Community Voices, Stories and Strategies (Report, May 2019) 7.

98 Four cases involved an arrangement whereby the unwilling party to the marriage was coerced into acting as a sponsor in a spouse or prospective spouse visa application. In one case, a partner visa application was contemplated but not lodged because the participant avoided the marriage. A sixth case involved a person 
Some participants expected that their family members would take the lead in making arrangements for their marriage, but problems arose when they objected to their proposed spouse. One interviewee was initially excited when her parents began to make arrangements for her to marry a man born in her parents' country of origin. However, when they spoke on the phone, she realised they were from 'two different worlds'; whereas she was 'all for female empowerment of women's rights', he suggested she should change the way she dressed and her hours of work. When her parents asked how things were going, she would say they were fine, but she 'withdrew' and 'kept to [herself]' and the situation escalated:

I would get a phone call and I would be yelled at and screamed at for being at work longer than I should be, for not being at home, for not talking to this person, not talking to my ex-fiancé ... I would get in trouble for that. I would get in trouble for not making an effort. I would get in trouble for not talking to my parents ...

$[T]$ here were many threats, many, many threats ... my dad was pretty close to hitting me ... ${ }^{99}$

She tore up her passport so she could not be taken overseas, but was 'in denial about what was happening' until she spoke to a friend. She explained:

My dad is very domineering. I can't say no to him. I can't say no to him in fear of being scolded, in fear of being a disappointment any further and for being a female, a failure. And of course, I couldn't say no to mum either because I didn't want to hurt her.

So, I was in denial about it for a long, long time until I spoke to a friend. ... [W] e were having a chat about what was happening and then she was like, no it's not what you think, it is actually a forced marriage. So, I think it took her to tell me, to make me realise it wasn't what I wanted; that it actually was a forced marriage..$^{100}$

Another interviewee was asked by her parents if she would be interested in meeting the son of a family connection. At the time, she 'hadn't had a whole ton of life experience' and thought 'what's the harm in just talking to someone'. But after speaking to him online, she 'wasn't really feeling it' and thought it was 'pretty much like having a pen pal'. Then, 'all of a sudden', his family members visited her house and plans were made for him to visit as well. She felt 'super naïve' because, looking back, she did not know how she 'did not see the red flags of the situation'. Then, one day, she returned from work to a house crowded with family and friends:

In front of everyone I get asked if I'm happy and then I was like I don't understand your question, what are you talking about? But I didn't say that, I think I was just quiet, which got misconstrued as 'oh she's just really really shy'. And the next thing I know, everyone is eating sweets because that's sort of something you do in a celebration and everyone's giving me money and hugging me and stuff .... that was it being decided. ${ }^{101}$

who was an applicant in a partner visa application but who subsequently elected to return to her country of origin. See generally Samantha Lyneham and Kelly Richards, Australian Institute of Criminology, Human Trafficking Involving Marriage and Partner Migration to Australia (Report No 124, 20 May 2014) 50.

99 Interviewee 7

100 Ibid.

101 Interviewee 2 (emphasis added). 
After the engagement, she told her parents she did not want to marry:

It was like somebody had died in the house, nobody was saying anything. It was complete silence, it was just like a black cloud was over the house and they were like okay don't say anything to anyone ... ${ }^{102}$

The cloud did not dissolve: over the following months, family members used subtle psychological tactics to coerce Interviewee 2 into marrying, while she sought to delay and avoid the marriage. Attempts to shame her into compliance were tied up with her family's notions of reputation and honour. For instance, when she refused to open a joint bank account with her fiancé:

$[\mathrm{M}] \mathrm{e}$ and dad had a massive fight but he was okay, and then when my mum came home and he told her what had happened and it got blown into a bigger - there was so much screaming - there was a lot of oh you're bringing shame on to the family; like what are we going to tell everyone, what are your grandparents going to think and so on ...

Some interviewees struggled to comprehend that their parents, with whom they had previously had positive relationships, would force them to marry. As the pressure to marry intensified, Interviewee 8 recalled: 'I went out for long drives, just to spend some time with myself because I was so mad at them. I was so mad. Why doesn't my mum support me? Why doesn't my dad support me?' However, another interviewee reported:

I always knew that [the forced marriage] was going to happen from a very, very young age, but I think [from] around 12 years old I knew that I was like going to be next. My two older sisters before me got married at 13 and $14 \ldots$ and I was the next girl, so I knew, you know, it was going to be me next ... ${ }^{103}$

While the experience of Interviewee 4 was marked by physical and psychological violence before the prospect of her marriage was raised, most interviewees reported that the marriage was preceded by a prolonged pattern of psychological coercion, rather than discrete incidents of physical violence. For example, Interviewee 1 faced continued threats and emotional abuse as his parents attempted to control his sexuality and make him conform to their expectations of gender roles. He explained:

I told my parents in the past by email saying I'm gay, I didn't want to get married to a woman. If I was forced to marry a woman, I would be miserable. They all knew that but ... my mother threatened me, threatened to disown me if I continued to be gay.

... My father, his response, well he was very angry saying that if I don't marry a woman and if I don't have a children then I won't be recognised as a proper man ...

In retrospect, Interviewee 1 identifies what happened next as a forced marriage but said 'at the time [he] did not realise that'. He explained:

At the time it didn't register in my mind that it was a forced marriage, but I was pretty much kind of gradually being, I [would] say groomed or brainwashed to think that this is something that I had to do.

Interviewee 1's use of terms such as 'grooming' or 'brainwashing' to describe the gradual application of coercion in the lead up to the marriage was used by other

102 Ibid.

103 Interviewee 4. This interviewee's experience was similar to the experience of forced marriage survivors who participated in a Spanish research study: Villacampa (n 92) 347-8. 
interviewees to describe similar experiences, including the cumulative impact of coercive behaviours, their lack of consciousness that they were under coercion at the time, and the sense that their situation was normal and that they had no choice but to go along with plans made by family members. For example, one interviewee reported that her parents had raised her to believe that early marriage was an inevitable and natural part of her life as a woman and that marriage would present her with freedoms that she did not enjoy in her family home. ${ }^{104}$

A number of interviewees $(n=4)$ feared family members would force them to marry in another country. These participants linked these fears to a lack of legal protections for women in the country where they feared marriage would occur, expressing concern that, once offshore, they would be isolated and unable to seek assistance because the marriage would be viewed, not as forced, but 'as normal' ${ }^{105}$

Most participants identified that their prospective spouse was offshore $(n=6)$ and the motivations for the marriage were intertwined with the desire to facilitate the migration of one party to Australia. For example, Interviewee 1 stated that his spouse knew he was gay, but threatened to publicly disclose his sexual orientation in his country of origin if he did not proceed with the marriage; as he was expected to sponsor his spouse for a partner visa, he believed she was motivated to act this way because 'she wants to live overseas one [way] or another'.

Participants all reported that controlling and coercive behaviours had a negative impact on their health, particularly as the pressure to marry intensified. For instance, Interviewee 7 said she was 'withdrawing' and 'falling apart' and her mother could see she was 'really unwell'. But when she told her mother that she did not want to get married, the same scenario would repeat itself:

[Mum would] go and tell my dad, he'd come back and I would say yes to him again, because I was scared of saying no to him. Because the repercussions were ... if you do this, I could never go back there again, they're going to kill your uncle, I'm going to [shoot] myself, I'm going to kill myself, we can never go there again ... you put a black spot next to your name. Nobody is ever going to respect you again. You have tarnished our name and your name.

As the cumulative effect of emotional abuse took its toll on their health, two interviewees sought medical treatment in conscious or subconscious attempts to avoid an impending marriage. One interviewee, who was taken offshore and forced to marry, explained that 'the pressure and emotional trauma' was so great that she 'never thought' she could stop the marriage:

Everybody was so keen, and everybody so wanted me to get married to him ... when I was in that environment and I stayed there for so long, I got so immune to it ... in my heart I was saying no but in front of everybody I was just quiet, you know I was just accepting everything as my fate ...

Once you are in the environment, you just got so immune to it, you know like domestic abuse or physical abuse, same with emotional abuse like you just so used to it like you don't know what's happening is affecting you internally, that's why I was having panic attacks, I was having asthma attacks, I was in hospital for so long.

104 The normalisation of early and forced marriage has been discussed previously: Villacampa (n 92) 5, 10; Australian Muslim Women's Centre for Human Rights (n 32) 11.

105 Interviewee 6. 
I never realised that, when I was in that situation, that it [was] actually affecting me, and I had depression ... I was self-harming, I was like suicidal ... ${ }^{106}$

Where a forced marriage occurred, the consequences were severe: some interviewees lived with physical violence, while others were subjected to emotional and economic abuse and coercive and controlling behaviours for prolonged periods. The process of extricating themselves from the marriage took months, sometimes years, and led to a profound sense of isolation and loss; one interviewee felt as if she 'disowned her family' by seeking a divorce and had 'lost them all' ${ }^{107}$ The diverse experiences of participants in this study underline the varied forms of coercion that can lead to forced marriage: pressure to marry can occur alongside other forms of violence or involve subtle non-physical forms of coercive and controlling behaviour over a prolonged period of time.

This study highlights the disjuncture between the lived experience of participants, who all described the disorientating effects of coercive and controlling behaviours that occurred over a prolonged period of time, and the legal definition of forced marriage, which focuses on whether a person consented to the marriage at the point in time it occurred. Drawing on a qualitative study with survivors of forced marriage in Scotland, Chantler and McCarry argue that the concept of 'coercive control', ${ }^{108}$ which is used to describe the subtle forms of control used by men to deprive their partners of their agency and autonomy, can be helpful in understanding the coercive and controlling tactics that family members may use to pressure a young person to enter into - and remain within - a forced marriage. ${ }^{109}$

This insight has resonance here: the harms associated with forced marriage did not begin or end with a marriage ceremony: ceremonies were preceded by months, sometimes years of emotional and psychological pressure and abuse, and that abuse continued, and often intensified, after the marriage occurred. The cumulative effect of prolonged exposure to coercion and threats took a profound toll on the mental health of participants, eroding their autonomy and their ability to envision a future in which they could enjoy freedom in their daily lives.

\section{Understandings of Forced Marriage and Family Violence}

In Australia, the intersections between modern slavery and family violence are not well-understood ${ }^{110}$ and this can create obstacles in identifying individuals at risk

106 Interviewee 5.

107 Interviewee 8.

108 The concept of 'coercive control' was coined by Evan Stark to describe the strategy used by men to psychologically isolate, break down and oppress women 'in personal life', including by targeting their agency and autonomy: Evan Stark, Coercive Control: How Men Entrap Women in Personal Life (Oxford University Press, 2009) 8, 200-10.

109 Chantler and McCarry (n 26) 91. See also Aisha K Gill and Deborah Gould, 'The Role of Family Coercion, Culture, Expert Witnesses and Best Practice in Securing Forced Marriage Convictions' (2020) 4(1) Journal of Gender-Based Violence 89, 90.

110 For further discussion, see Lyneham and Richards (n 98) 50; Marie Segrave, Bodean Hedwards and Dinar Tyas, 'Family Violence and Exploitation: Examining the Contours of Violence and Exploitation' in John Winterdyk and Jackie Jones (eds), The Palgrave International Handbook of Human Trafficking (Palgrave Macmillan, 2020) 439. 
of forced marriage and barriers accessing legal remedies and support services. In 2016, the Victorian Royal Commission into Family Violence reported that forced marriage was 'not readily recognised as family violence' and frontline responders may lack knowledge of the law and support that is available. ${ }^{111}$ Consistent with earlier research, the findings of this study suggest that people facing forced marriage may not initially identify their experience as forced marriage or family violence because they lack knowledge of the law and their legal rights, ${ }^{112}$ and, in some cases, may feel uncomfortable associating the actions of family members with the terms 'forced marriage' or 'family violence'.

Most participants did not initially identify their experiences as forced marriage or family violence; it was generally only after seeking out information or leaving the forced marriage that they connected their experiences with these terms. ${ }^{113} \mathrm{In}$ retrospect, interviewees generally considered that the term 'forced marriage' was reflective of their experiences, contrasting the pressure or force they felt to enter a marriage or relationship with the freedom to choose or 'have a say' in a proposed marriage. One interviewee considered the term 'forced marriage' was a 'good term' because it was 'short and easy', accurately describing how 'you don't have a choice. You don't have any say in that marriage and it's forced upon on you'. ${ }^{114}$ However, while Interviewee 7 believed forced marriage should be criminalised, she found the term 'forced marriage' to be 'really unempowering', explaining that while it is as bad as it sounds ... you don't think it's actually happening to you.

To me it was, you know what, it's just my parents and I disagreeing, I'm not getting along with this person, things will change ... But you can't imagine your own parents doing that to you though. That's where it's kind of was like, you know what, it's not a forced marriage, it's just an arranged marriage that we're having some disagreements [about] ... I think even now labelling it as a forced marriage is still a struggle. ${ }^{115}$

She explained that she struggled with labelling her experience as forced marriage or family violence, primarily because of the stigma of criminality that both terms brought to her understanding of her relationship with her parents:

I don't think labelling it as family violence or forced marriage is particularly [helpful] ... [however] some people they may need those terms to label what's happening for them. ... People that commit family violence, who push their children to do things

111 Royal Commission into Family Violence: Report and Recommendations (Report, March 2016) vol 5, 121. For example, the 2016 Victorian Royal Commission into Family Violence observed that forced marriage can represent an 'intersection between family violence, sexual exploitation and child protection', but that some forms of family violence in cultural and linguistically diverse communities, including forced marriage, 'are not readily recognised as family violence': at 111, 121 . The Commission heard that 'some young women facing forced marriage who turned to authorities or professionals for help did not receive appropriate assistance because those from whom it was sought lacked the knowledge of the law and support that is available': at 111.

112 This is consistent with earlier studies showing that young women at risk of forced marriage were 'overwhelmingly unaware of any legal rights and protections they had under Australian law': Prattis and El Matrah (n 81) 26. In the context of the United States of America, see also Love et al (n 33).

113 Participants were asked about their understandings of the terms 'forced marriage' and 'family violence' and whether they considered these terms described their experience.

114 Interviewee 5.

115 Interviewee 7. 
they don't want to do - I don't want to associate my parents with those people, because they're still my parents. And I just feel what they've done is wrong and from a professional point of view they did the worst thing ever. But I can't see them being criminals.

All participants were unaware of whether Australia had laws prohibiting forced marriage that would have reassured them that they were right to resist the marriage and may have assisted them in their efforts to change the attitudes of family members:

I also didn't realise that it was illegal ... So I don't know if making that more obvious in some way to people, not just to the person [at risk of forced marriage], but like you know their family members, because they won't see it that way ... they just think that they're doing what's best either for the family or for culturally or religiously; they don't realise, and they don't think of it that way. ${ }^{116}$

Participants were all familiar with the term 'family violence', but most did not classify their experience as family violence, sometimes because they incorrectly assumed that family violence involved physical abuse from a spouse but not psychological, emotional or economic abuse from relatives or were unsure whether the controlling and coercive actions of their family members could be described as 'violent'. This uncertainty was expressed by three interviewees:

I guess domestic violence would be like, I guess almost the obvious, like the physical, emotional abuse, things like, or just being under someone's control constantly, like that kind of thing. Violence itself is a very strong word and I feel like it wasn't physical at all but there was a lot of verbal abuse and a lot of emotional blackmail so I don't know if that falls into the same sort of category but that was what it was. ${ }^{117}$

I wouldn't say it's just family abuse, because that was one part of the issue, but it wasn't the whole issue. But I don't necessarily think you have to be violent to have a forced marriage so those issues don't necessarily correlate. ${ }^{118}$

Sometimes forced marriage does not necessarily mean family domestic violence because you might be forced into a relationship but maybe that partner would never be like violent to you. Maybe he doesn't have a choice ... I know some people that their husbands are also being forced in that relationship ... there's no family violence but they live together for the sake of family and for the sake of the community. But that can be very rare, and I would say around $90 \%$ of forced marriages does involve family violence. ${ }^{119}$

While Interviewee 4 had experienced violence at the hands of family members, she explained that 'a lot of girls' were told they had to get married by family members who 'have never hurt them or done anything ill towards them'. Interviewee 5 acknowledged that the family members who pressured her to marry were themselves under pressure from other community members to uphold the existing marriage commitment:

I don't think I would label [my experience] as family and domestic violence ... I know that even my brother was against this [marriage] ... but because he didn't have a choice and the decision was already made ... [my] family wasn't willing to deal with all these community issues, conflicts ... getting isolated from the community. 
There's so much stigma attached to the person who's getting divorced [that] for the family to be in the community is absolutely a nightmare.

Another interviewee reflected that he would now describe his experience using the terms 'family violence' and 'forced marriage', but he had only become aware of these terms after he left the abusive situation, recalling: 'At the time I had no clue. I didn't realise what was going on. I just knew that I felt I have [to] do those things' ${ }^{120} \mathrm{He}$ explained that when he read information online about family violence, forced marriage was mentioned and 'then I clicked a link onto it and saw a description [of forced marriage] ... I then had an awakening moment and I was like oh my god this is exactly what happened to me'.

Forced marriage is now specifically recognised as a manifestation of family violence in three jurisdictions in Australia, and a recent Commonwealth parliamentary inquiry recommended a consistent national approach to defining family, domestic and sexual violence, which encompasses 'a broad range of violence', including forced marriage. ${ }^{121}$ However, this study suggests some people facing forced marriage may not initially identify themselves as victims as they may not associate controlling and coercive behaviours by family members with the term 'family violence', particularly when the behaviour does not involve physical abuse by an intimate partner. This highlights the limitations of law reform that explicitly identifies forced marriage as a form of family violence, without seeking to understand and describe the patterns of coercion associated with forced marriage; the ways in which forced marriage can overlap, intersect or co-occur with other forms of family violence; or supporting community awareness and denunciation of these practices. Therefore, statutory recognition of forced marriage as a form of family violence must be accompanied by holistic strategies that support the identification of people at risk of forced marriage and are sufficiently flexible to enable different forms of support, protection and redress to be tailored to individual needs and circumstances.

\section{Resistance and Obstacles to Help-Seeking}

\section{Barriers to Help-Seeking}

All the participants actively sought to avoid or leave the marriage. Attempts to seek help were driven by the desire to avoid an imminent marriage, the impact of coercion or threats on their mental health, or the need to escape the threat of sexual violence or physical abuse. All interviewees who had been forced to marry wanted to erase the legal and cultural implications of their marriage and, as far as possible, restore themselves to the position that they were in before the marriage. Most interviewees also wanted to find a way to avoid or leave the marriage without moving out from the family home or becoming estranged from their family and community, although some interviewees identified that this outcome was not possible.

120 Interviewee 1.

121 See above n 13. 
The normalisation of coercive and controlling behaviours over a prolonged period of time within a family setting posed a barrier to help-seeking. Most interviewees $(n=6)$ lived in the family home where their behaviour was monitored and, even if they were over the age of 18 , lacked the financial resources to establish themselves outside the family home. In all but one case (involving an intimate partner), the family members were involved in forcing the interviewee to marry or preventing them from exiting the marriage. The majority $(n=6)$ also faced coercion or, in some cases, abuse from the person they were being forced to marry and/or their family members.

A number of interviewees $(n=4)$ had positive relationships with their family members before marriage was proposed, while others disclosed a history of family violence that predated the threats to marry $(n=3)$. Even when interviewees identified some family members as abusive, they often spoke of positive relationships with others in their immediate or extended family who either actively supported, or were sympathetic to, their efforts to resist the marriage. Most interviewees $(n=6)$ were concerned that seeking assistance from the authorities would endanger family members or compromise their family's reputation within close community groups and initially sought to persuade family members that the marriage should not occur. ${ }^{122}$ Three participants sought, with ultimately no success, to delay the marriage on the basis that they wanted to complete their studies. For instance, after Interviewee 6 obtained her Higher School Certificate ('HSC') result:

I questioned [my Dad], and he was quiet and then I asked him, like I kept asking him, like we have to go back [to Australia] ... I want to go back and I want to study $\ldots$ [and] then he said, 'oh you're not going back'. ${ }^{123}$

Participants often acted against their own interests to preserve family relationships. One interviewee explained that, in her case, there 'was never physical abuse' and that contacting the police was difficult, if not impossible, for individuals from close-knit families because 'there's a bond there'. She explained:

So you don't want to get [your family] in trouble in a way because there is love there and something like calling the police just feels like it would be tearing that all apart; any amount of decency that the situation could end in would be torn apart ....24

As with earlier studies, interviewees often lacked knowledge about their legal rights and how to seek assistance. ${ }^{125}$ When first confronted by the prospect of a marriage that they opposed, most interviewees sought informal support from trusted friends or family members or medical professionals and, in most cases,

122 Participants told family members about their objections to the marriage but when family members stated the marriage would occur notwithstanding those objections, participants identified other objections to the marriage that they thought might be shared by the parents. For example, Interviewee 2 sought to convince her parents that her prospective in-laws failed to show their family due respect. Interviewee 6.

124 Interviewee 2.

125 Prattis and El Matrah (n 81) 28; Lyneham and Bricknell (n 33) 58, 88, 96; Gill and Gould (n 109 ) 101. Within the context of family violence more generally, lack of awareness and understanding of legal remedies can similarly pose a barrier to reporting: Law Council of Australia, The Justice Project: People Who Experience Family Violence (Final Report No 1, August 2018) 27. 
armed themselves with information they found online. After initially seeking advice from friends, one interviewee sought information and reassurance online:

I would hop on that 1800 respect site a lot and just chat to a new person every single night and just tell my story over and over ... I kept looking for somebody to kind of confirm what I thought it was, that it was family violence and it was my dad being coercive, being manipulative, blackmailing me and what not. But I couldn't see that for myself. I needed somebody to tell me it was actually happening. ${ }^{126}$

Some participants became aware of laws addressing forced marriage and family violence while searching for advice online. For example, one participant sought out information on getting married under Australian law and recalled reading that: 'you shouldn't be under duress and I felt that I was [and] it was at that point I kind of clicked that oh this is, this is what's happening'. However, she did not feel confident to seek help before the marriage occurred, because the celebrant was a family friend and she felt like she had 'nowhere to go'.

Even when participants obtained information about the legal responses to forced marriage, for many interviewees, decisions about seeking help were driven by concerns for family members. ${ }^{127}$ While interviewees all agreed forced marriage should be illegal, a significant number $(n=4)$ reported that they would not go to the police or seek a civil protection order because of fears for family members (one of these participants explained she did ultimately speak to the AFP, but only after being reassured she did not need to make a police statement). Interviewee 6 identified the dangers of making support conditional on having contact with the police, especially in cases involving young girls who feared losing their relationship with their parents:

That's why the young girls are getting married very [young] at 13/14 and not telling the authorities, [it's] because of this emotional trauma, this emotional abuse that if I'm going to go to the authorities our parents are going to leave us ... they're going to take my parents away.

Another interviewee stated that she would have only gone to the police if she felt her life was at risk from her husband's family or her own, but she was also concerned that, if she went to the police, this action would heighten her risk of being harmed or killed. She stated that, if she went to the police, her family 'would get upset' and 'never ... leave me alone'. She explained:

They [my family] would put a lot of pressure on me like to convince me not to leave the relationship and, at the end of the day, I'm part of that family. And by going to police I wouldn't solve my problem, it would create more problems. ${ }^{128}$

The majority of interviewees were forced to marry $(n=5)$ and sought and obtained a divorce under Australian law or Sharia law, although most $(n=4)$ encountered stigmatisation and emotional abuse during the process of doing so. The process of obtaining an annulment under Australian law was either not considered or, in the one case where it was, viewed as more difficult than obtaining

126 Interviewee 7.

127 This is consistent with the findings of empirical studies with survivors in the UK: see, eg, Marianne Hester et al, Victim/Survivor Voices: A Participatory Research Project: Report for Her Majesty's Inspectorate of Constabulary Honour-Based Violence Inspection (Report, 31 August 2015). 
a divorce. ${ }^{129}$ For participants of faith, it was important to obtain a divorce under religious law notwithstanding the social opprobrium they encountered for doing so. ${ }^{130}$ For instance, after Interviewee 5 sought a divorce, her family members refused to speak to her for months even though they resided in the same house, and she faced pressure to move out so her family could avoid 'pressure and stigma' from community members. However, she remained firm in her resolve to obtain a divorce, undertaking her own research about the grounds for a religious divorce and 'trying to use [her] religion to convince [her] family' that 'consent is the most important thing'.

Interviewees faced additional obstacles leaving a forced marriage when their marriage was intertwined with the passing of money and gifts between families and connected to an ongoing application for a partner visa. One interviewee, who was the sponsor in a partner visa application, contacted the Department of Home Affairs ('the Department') to find out if she could withdraw her sponsorship but was told it was impossible to do so without her husband knowing she had done so, a risk she was not prepared to take. Without seeking her consent, the Department referred her matter to the AFP. Despite her fear, she declined to disclose her circumstances to the AFP and did not consider obtaining an intervention order against her family or moving out of the family home, because of her fear of getting her family in trouble. She explained that when she met with the AFP:

I change[d] my words, I didn't say that there was a forced marriage or anything because I don't want my family to go through, you know, bad times. ${ }^{31}$

She was not referred to the STPP and refused to have further contact with the AFP. Her experience highlights the problem of conditionality: because she was unwilling to disclose her true circumstances to the AFP, she was not able to access support under the STPP.

Some interviewees $(n=2)$ reported that seeking a divorce exposed them to coercion, intimidation and stigma as their husbands, in-laws or family members sought to keep them in the marriage. For instance, Interviewee 5 withdrew her sponsorship of her husband's partner visa when he was still offshore in an attempt to prevent his arrival in Australia. The Department did not inform her that her husband would be told that she had withdrawn her sponsorship and she felt unprepared for

129 For example, one interviewee wanted to apply for an annulment of the marriage under Australian law but acted in accordance with legal advice to apply for a divorce.

130 For instance, Interviewee 5 explained that obtaining an Australian divorce 'wouldn't solve my religious issues' because she would not be able to remarry without a religious divorce, observing that she felt that 'the religious divorce is more important than the Australian divorce'. However, sometimes this process was complicated by the fact that the religious and legal status of cultural or religious ceremonies was unclear. This was particularly apparent in cases where the religious ceremony did not involve the physical presence of one or more of the parties to the marriage. For instance, Interviewee 7 was uncertain whether she had been married because her dad told her that 'the nikah has happen[ed]', 'you are religiously married' and 'we need to officially end this'. She explained that, while she knew there was no marriage under Australian law, she did not know whether there had been a religious marriage because:

I don't have any proof of anything [and] ... when I told him, my ex-fiancé that I don't want this, I don't want anything to do with this anymore, he goes ... religiously you are my wife ... you don't get a divorce until I say so. So I don't know what's happening overseas ... 
the 'nightmare' of being pressured to 're-sponsor' him by a religious leader as well as family members. When she resisted, her husband's family demanded that she pay them a large sum of money. Because she did not believe she would be able to obtain the divorce without paying the money, she agreed to do so even though she knew 'he has no right to ask me to pay money'. She explained:

You can earn money, but I was always feeling like I was in a cage, like I never felt free. It doesn't matter what I was doing, I was always thinking that I am literally like in a cage, in a prison and I never never had that freedom that I have got now. So ... I was thinking to myself, I was saying, that it's going to be worth it, at the end of the day me feeling happy and free is what I really want ... the impact that it was having on my health was not something that I could buy in the future with money.

The current partner visa regime is not designed to respond to allegations of forced marriage (whether raised by the applicant or the sponsor). ${ }^{132}$ Women with insecure migration status can be particularly vulnerable to family violence, including forced marriage, because they fear seeking help will jeopardise their immigration status or result in their removal from Australia. ${ }^{133}$ The "family violence exception' to the requirement that applicants for a permanent partner visa be in a genuine, continuing relationship is intended to prevent people from remaining in abusive relationships to avoid threats of deportation. However, this exception is not designed to protect victims of forced marriage who were never in a genuine relationship ${ }^{134}$ and provides no protection to women facing family violence on a range of temporary visas. ${ }^{135}$

Most participants were Australian citizens or residents and half $(n=4)$ were sponsors in partner visa applications, while the partner visa of one participant was sponsored by a partner who forced her to remain in a relationship. One interviewee found the divorce process under Australian law 'relatively simple' but this was only after she had secured her family's support to end the marriage and made it clear to her husband and her family that she was not going to withdraw her sponsorship of

132 Simmons and Burn (n 53) 1002-4. See Lyneham and Bricknell (n 33) 77.

133 Marie Segrave, 'Temporary Migration and Family Violence: The Borders of Coercive Control' in Kate Fitz-Gibbon et al (eds), Intimate Partner Violence, Risk and Security: Securing Women's Lives in a Global World (Routledge, 2018) 126, 131, 136. In her analysis of how the state contributes to vulnerability in family violence, Segrave extends the individualised concept of 'coercive control' to the state - through its migration regime, the state exercises coercive control over women with temporary migration statuses by restricting their support and rights and by enabling perpetrators, who are citizens or permanent residents, to control women by threatening to withdraw sponsorship of partner visa applications. See also Royal Commission into Family Violence: Report and Recommendations (Report, March 2016) 109.

134 Simmons and Burn (n 53) 1002-4.

135 See generally Australian Law Reform Commission, Family Violence and Commonwealth Laws: Improving Legal Frameworks (Report No 117, November 2011) 493-9. The Australian Law Reform Commission ('ALRC') recommended that the family violence exception should be expanded to cover a wider range of visa subclasses: at 496,499 . The ALRC also recommended that a new temporary visa be created to allow victims of family violence to remain in Australia for a temporary period to access support services and make arrangements either to return to their country of origin or to apply for another visa: at 503. These recommendations have not been implemented. The Victorian Royal Commission into Family Violence did not express a view on the ALRC recommendations but considered that the family violence provisions should be extended to a person who suffers violence from a non-spousal family member: Royal Commission into Family Violence: Report and Recommendations (Report, March 2016) vol 5, 125. See also Segrave (n 133) 129-30. 
his partner visa. However, in three cases, participants reported they believed the pressure from family/their spouse to remain in the marriage was greater because they were sponsoring their spouses' partner visa applications and there was an expectation that their spouse would obtain a permanent partner visa.

\section{Interactions with Frontline Officials}

When participants had contact with frontline responders, their confidence in the capacity of the justice system to protect their rights was shaped by whether they felt officials took their concerns seriously and whether they were provided with information about the decisions that were made about their case. This is consistent with research which highlights how victims' experiences of interactional justice in their contact with justice actors, such as the police, can either enhance their experience of the justice system or discourage them from seeking further help. ${ }^{136}$ As discussed earlier, most participants first sought advice from informal sources and were initially unaware that they could seek official assistance or were reluctant to do so. Most participants $(n=6)$ ultimately approached government agencies (state or federal police, an Australian embassy or the Department) to seek assistance to leave home, return to Australia, extricate themselves from a partner visa application, or protect themselves from violence and abuse. Participants generally approached authorities directly, sometimes as a result of a referral from a non-governmental organisation ('NGO') or trusted confidant.

However, almost all interviewees $(n=4)$ who sought help from authorities encountered a low-level understanding of forced marriage and low sensitivity to the risks of further harm. Officials sometimes showed little or no understanding of their circumstances and did not always provide appropriate referrals to support services or legal advice. Some participants reported that the initial response by frontline responders failed to acknowledge the risks that they had taken in reporting their situation or the harm that they were facing. For instance, frontline officials encouraged participants to return home $(n=2)$, initially did not believe their claims $(\mathrm{n}=1)$ or did not offer practical assistance to return to Australia $(\mathrm{n}=1)$. In separate interactions with multiple police officers over an extended period of time, Interviewee 3 , who was subject to reproductive coercion from a violent partner, was initially told that her fears were not serious enough to warrant police seeking a protection order. While her partner was subsequently convicted of a criminal offence, she only received an apology and assistance from a specialist domestic violence police officer when a Legal Aid solicitor at a local court called the police on her behalf.

Another participant, who was threatened with forced marriage before it was criminalised in 2013, recalled that, after running away from home and seeking help from state police, she was treated like a 'belligerent teenager'. She recalled:

136 See generally Natasha Mulvihill et al, "The Experience of Interactional Justice for Victims of "Honour"Based Violence and Abuse Reporting to the Police in England and Wales' (2019) 29(6) Policing and Society 640. Interactional justice relates to how respected and informed victims feel in their encounters with justice officials: at 642 . It can impact not only victims' level of satisfaction with the justice system, but also their mental health, ability to cope, sense of self-worth and sense of societal belonging: at 642 . 
[O]ver and over, like I kept explaining you don't understand, they are violent, they're abusive, they're trying to take me overseas, they're trying to, and like it just wasn't clicking, they just kept saying, what's the address, we'll go and talk to them, what's the number, we'll call them. I'm like, you really don't understand, if I go back, I will be taken overseas and I will never come back here again. ${ }^{137}$

Eventually, Interviewee 4 stopped talking to the police. A social worker from a child protection agency picked her up and took her to emergency housing and, despite the shock of being placed in unsafe and inappropriate accommodation, she never returned to the family home.

Two interviewees were positive about their interactions with AFP officers, highlighting the value of safety planning in preventing further harm. ${ }^{138}$ For instance, Interviewee 7, who only agreed to talk to the AFP after being reassured that she did not have to make a police statement, found the experience helpful: she was referred to the STPP where she was supported to leave the family home, and she felt reassured - she knew who to call for help if 'things become worse'. She met with the AFP on multiple occasions, observing it was 'great to ... get the help but not have to prosecute' and to have the 'security' of knowing she could contact the AFP 'in case [she] needed help ASAP'. She said she never felt pressured to make a police statement and would '100 percent' refer others facing forced marriage to the AFP. Another participant recalled that AFP officers helped him understand the investigation process and referred him to the STPP, and that his interactions with both the AFP and the STPP were important to him in validating his experience. ${ }^{139}$

A fourth interviewee sought assistance from the Department of Foreign Affairs and Trade ('DFAT') and the AFP after she was forced to marry overseas and had her travel documents taken from her to prevent her from returning to Australia. ${ }^{140}$ An embassy official told her that they could give her a loan to help pay for her trip back to Australia but it was going to take a long time to get approved, before questioning her desire to leave:

I still remember her voice ... she straight away told me this that oh are you sure you want to go? Because, you know ... lots of girls who leave always end up back in

137 Interviewee 4.

138 Five interviewees had contact with the AFP.

139 Interviewee 1. See generally Mulvihill et al (n 136) 650.

140 Australian citizens who are overseas and have had travel documents taken from them can apply for an emergency passport to be issued at an Australian diplomatic or consular mission. If a child seeks an emergency passport without consent from those who have parental responsibility for the child and there is no relevant court order, the Australian Passports Office will consider issuing a passport under special circumstances as per section 11(2) of the Australian Passports Act 2005 (Cth) and section 10 of the Australian Passports Determination 2015 (Cth). Special circumstances include where the child is outside Australia and there is evidence of family violence or if the Minister considers there is a need for the child to travel internationally: 'What if Nobody Consents to a Child Passport?', Department of Foreign Affairs and Trade (Web Page, 15 July 2020) <https://www.passports.gov.au/how-it-works/how-getchild-passport/parental-responsibility-and-consent/what-if-nobody-consents>; 'Emergency Passports', Department of Foreign Affairs and Trade (Web Page, 15 July 2020) <https://www.passports.gov.au/ getting-passport-how-it-works/special-travel-documents/emergency-passports>; 'Incomplete Consent', Department of Foreign Affairs and Trade (Web Page, 15 July 2020) < https://www.passports.gov.au/howit-works/how-get-child-passport/parental-responsibility-and-consent/what-if-not-everyone\#special $\% 20$ circumstances $>$. 
[country] because it's very hard for you girls because we've been living in a bubble for all our lives to live on our own in Australia. ${ }^{141}$

The embassy referred her to the AFP, but all the AFP did was 'ask questions' and advise her to return to Australia where they could assist her. When she eventually returned to Australia without official assistance, she contacted the AFP and was told that she would be contacted by someone who could assist with her living arrangements, but this did not happen, and she did not contact the AFP again. Her account of the insecurity she experienced over many months as she sought to re-establish herself (she borrowed money and felt pressured to stay in unsafe housing while looking for a job) brings into focus the isolation and vulnerability of individuals after they have avoided forced marriage and the need for long-term support to protect against further harm..$^{142}$

A fifth interviewee, who had avoided a forced marriage by fleeing the family home, later contacted DFAT and the AFP to ask them to help her sister, who had been taken offshore and forced to marry. This interviewee recalled making multiple reports to both DFAT and the AFP, and being referred back and forth between the agencies without being told what steps were being taken to assist her sister. At the same time, she was aware her father was continuing to travel in and out of Australia:

Every time he came, I would call and say ... he's back in Australia, are you going to arrest him, are you going to talk to him, are you going to do anything? It was just oh we'll make a note of this and we'll look into it and literally nothing. ${ }^{143}$

Jurisdictional or operational constraints may limit the assistance that government agencies can provide offshore. However, the failure of authorities to explain what attempts had been made to render assistance, coupled with the confusion about which agency was responsible for providing assistance, led two participants to conclude that the authorities had not taken their complaints seriously. The heightened complexity and risk in offshore cases illustrate the need for multi-agency guidance about responding to cases of forced marriage in Australia and offshore. Guidance should make clear the responsibilities of each agency involved and mandate referrals to NGOs for support offshore and onshore, when victims return to Australia. There is also a need for training for frontline government and non-government services to promote greater understanding of the nuances and processes of coercion and control that can occur before any marriage or engagement ceremony.

\section{Seeking Reassurance and Asserting Independence}

The majority $(\mathrm{n}=7)$ of interviewees valued receiving support from nongovernment sources, including information about forced marriage, access to safe housing, financial assistance, safety planning, free legal advice about immigration and family law matters, work experience and counselling, and what half of the interviewees described as reassurance that they were right to resist a forced marriage.

141 Interviewee 6.

142 See generally Gill, Cox and Weir (n 57) 590.

143 Interviewee 4. 
Consistent with an earlier study, participants often recalled the demeanour and responses of the first frontline official they encountered in detail ${ }^{144}$ and emphasised the importance of officials recognising the risks involved in seeking assistance. For instance, one interviewee described her sense of hopelessness when an embassy official was 'unresponsive' to her situation, explaining that it would have 'been more helpful' to have

just a reassurance that, you know, you can come back ... that's what I think is really important for women who have been in this situation. Because they've been dealing with all this and then they call for somewhere to help and ... they are so unresponsive ... there's no hope ... ${ }^{145}$

Participants explained that reassurance strengthened their resolve to resist the marriage and acted as an antidote to pressure from family members. This reassurance could take different forms, from provision of information about support services to

[j] ust listening. Even if it's validating. Like you know validation of your emotions and what you go through ... that makes a lot of difference I guess because at least you know okay there's a person that I can count on or go to when I feel down and when I'm so lost and confused about [what] to do. Because you know, she knows the culture, she knows what is happening like what would be appropriate for the community or you know what other support you can get rather than like, instead of involvement from authorities ... ${ }^{146}$

As noted above, the emotional toll of prolonged exposure to psychological coercion was profound, and most participants $(n=5)$ accessed counsellors, with most $(n=4)$ reporting counselling was helpful. ${ }^{147}$

In addition to reassurance, participants wanted practical assistance to leave the family home and assert their independence in a safe, secure environment. For Interviewee 7, contacting the AFP was important because it gave her access to the STPP: the STPP caseworker provided 'support in looking for places to stay' as well as bond money for rental accommodation, support meeting educational costs, a safety plan, and a referral to a counselling program. As she explained, this support was transformative because outside the family home

you can start again, you can do your own thing. They can't control you; they can't make you do anything, your parents can't do all those things to you ... things just got so full on at home that I couldn't, I couldn't do it anymore, I just mentally and physically couldn't be in that household anymore.

Consistent with earlier studies, ${ }^{148}$ interviewees $(n=5)$ explained that their capacity to avoid or exit a forced marriage depended on their ability to access financial support and safe accommodation. Some participants noted that placing young people facing forced marriage in inappropriate accommodation could

144 Mulvihill et al (n 136) 650 (this study involved victims of honour-based violence, including victims of forced marriage, and noted that 'almost all [victims] could recall in detail the demeanour of the responding officer(s)').

145 Interviewee 6.

146 Interviewee 5.

147 Most participants accessed counselling directly through educational institutions or general practitioners, or as a result of a referral through the STPP or the local court after seeking a domestic violence order.

148 See Villacampa (n 92) 362; Lyneham and Bricknell (n 33) 61. 
discourage them from seeking further assistance, and recommended investing in housing designed for young women at risk of forced marriage. ${ }^{149}$

Family attitudes were not static. Most participants initially sought to change family members' views about marriage but were unable to do so before the marriage occurred. But sometimes the attitudes of family members did change over time: two participants ultimately obtained acknowledgement from the family members who had forced them to marry that their actions were harmful (but only after the forced marriage had occurred). Even when participants did not receive such acknowledgement, they still sought to renegotiate their relationships with family members with varied results: two interviewees were able to continue living in the family home after avoiding or leaving a forced marriage, while others cut all contact with family members who failed to acknowledge their wrongdoing, ${ }^{150}$ or only sought to re-establish contact after they were living independently from their family and the marriage had ended. Two interviewees identified that learning how to relate to their family while living independently was a necessary strategy to avoid the risk of being forced to marry in the future.

This study points to the need to grapple with the reality that, in most cases, people facing forced marriage will maintain connections with family members and have long-term safety needs that may extend beyond any placement on the STPP or engagement with the AFP. The lack of mediation/family conflict resolution services has been identified as an unmet need of clients of the forced marriage stream of the STPP, ${ }^{151}$ and research with affected communities highlights that 'the pressures that can drive a forced marriage' can sometimes be felt not just 'by the individual, but at times by the whole family'. ${ }^{152}$ While acknowledging concerns that mediation can expose people at risk of forced marriage to further harm, ${ }^{153}$ experiences of forced marriage are varied and further research could explore what,

149 For example, Interviewee 4 explained that, because she grew up in a 'very controlled environment' and was taught that the 'outside world is evil', she was 'terrified' when she fled her home and got placed in emergency accommodation with teenagers using drugs. She recommended that 'they should have specific houses for girls who come out from this situation [facing forced marriage]', noting that the last house she stayed at was specifically for girls from 'families that were abusive' and that they all supported each other, which had a 'positive effect all around, as opposed to living in a negative environment and ending up in another negative environment'.

150 For instance, Interviewee 4 said that, on the one occasion she spoke to her mother on the telephone after she had fled the family home, '[she] just started yelling like why would you do this, you shamed our family'. The interviewee 'decided never to bother again', explaining 'I've not spoken to, or seen them since then'.

151 The evaluation of the STPP forced marriage stream noted that, in some cases, clients have returned home 'as the prospect of a forced marriage is comparatively less confronting than the alternative - isolation from family, friends and community, and creating shame for the family - and they have a lack of confidence in any viable solutions to their situation': Stacey and Boniface (n 49) 16.

152 Australian Red Cross, Forced Marriage: Community Voices, Stories and Strategies (Report, May 2019$) 51$.

153 UK Government, Multi-Agency Practice Guidelines: Handling Cases of Forced Marriage (Guideline, June 2014) 25, 70. 
if any, utility restorative justice strategies, ${ }^{154}$ such as cross-cultural mediation, ${ }^{155}$ could have in situations where people who have resisted a forced marriage seek to re-establish connections with family members. ${ }^{156}$

\section{LEARNING FROM LIVED EXPERIENCE: IMPLICATIONS FOR LAW AND POLICY REFORM}

\section{A Alternative Pathways to Justice}

The varied help-seeking behaviours of participants points to the need to look beyond the criminal justice system and adopt a multifaceted approach to forced marriage as a harm which can be identified, prevented or remedied in different frameworks. People facing forced marriage may interact with different areas of the Australian legal system: they may be entangled in family law or immigration proceedings which can, in turn, impede their capacity to leave the marriage, or their

154 While there is no universal definition of restorative justice, the United Nations Office on Drugs and Crime describes it as 'any process in which the victim and the offender, and, where appropriate, any other individuals or community members affected by a crime, participate together actively in the resolution of matters arising from the crime, generally with the help of a facilitator': United Nations Office on Drugs and Crime, Handbook on Restorative Justice Programmes (Handbook, $\left.2^{\text {nd }} \mathrm{ed}, 2020\right) 5$.

155 Daniela Danna and Piera Cavenaghi, 'Transformative Mediation in Forced Marriage Cases' (2011) 17(2) Interdisciplinary Journal of Family Studies 45. Danna and Cavenaghi provide an overview of transformative mediation or cross-cultural mediation, which has been made available to victims of honour-based violence in Denmark and proposed by Farwha Nielsen, a cross-cultural mediator: at 48. In transformative mediation, the role of the mediator is not to take on a neutral position, but to act 'on the basis of his or her values, consciously trying to defend the rights of the weakest parts'. The cross-cultural mediation process is based on the assumption that, when faced with the dichotomous options of breaking all contact with family or returning to a violent family situation, a victim will choose to remain or return to their family: at $47,52,57$. The model encourages dialogue between the parties, with the support of various government agencies, to find solutions to the family conflict in a controlled manner, which is often impossible without a mediator because of the hierarchical nature of the family: at 51. The purpose of the mediation is to work towards the signing of a contract by the parties (generally between the parents and the child) which contains guidelines about how the family can contact the victim, safe ways for the victim to contact support services, and more: at 51.

156 See generally Askola (n 53) 1000. For discussion on the role of family mediation in forced marriage cases and the UK's position to not support mediation given the risks of using it in situations involving children and/or violence, see Danna and Cavenaghi (n 155); Askola (n 53); Lyneham and Bricknell (n 33); Ralph Grillo, Muslim Families, Politics and the Law: A Legal Industry in Multicultural Britain (Ashgate, 2015) 257. In the Australian context, Lyneham and Bricknell noted that local stakeholders were divided on the role of mediation, with most opposing its use, but recommended that such a model in which the mediator is supported by service providers, law enforcement and legal professionals 'might be considered for cases in Australia in which conditions of safety can be guaranteed': Lyneham and Bricknell (n 33) 85. This is consistent with recommendations from Stacey and Boniface (n 49) that the Australian Red Cross consider identifying and implementing strategies that better address forced marriage clients' needs on the STPP, such as services that can assist clients with family mediation or conflict resolution. Workshops held by Farwha Nielsen in NSW and Victoria in 2019, with the support of Good Shepherd Australia and New Zealand, raised the prospect of considering a cross-cultural transformative mediation model within an Australian context: Laura Vidal, 'The Art of Helping: Lessons for Australia in Taking a Mediation Approach to Forced Marriage', The Power to Persuade (Blog Post, 19 March 2019) <https://www. powertopersuade.org.au/blog/the-art-of-helping-lessons-for-australia-in-taking-a-mediation-approach-toforced-marriage/18/3/2019? rq=farwha $>$. 
experience of forced marriage may overlap or intersect with other forms of family violence, sexual violence and other slavery-like practices. All interviewees $(n=8)$ reflected on the limitations of the law in addressing the needs of people facing forced marriage and drew attention to the importance of education initiatives, access to safe accommodation, and support services, including counselling and safety planning, in creating an environment in which they could assert their autonomy and make choices about their work, education and relationships.

We found a common barrier to seeking assistance was that people did not initially identify their experience with the terms 'forced marriage' or 'family violence' and lacked information about their legal rights, how to protect themselves, and how to access support. ${ }^{157}$ This study highlights the important role that digital information, friends and family members often played in informing people about their legal rights and accessing support services. More must be done to help victims identify the warning signs, understand their legal rights, and access assistance as well as to build the capacity of frontline responders to identify forced marriage and provide appropriate referrals to specialised support and advice services. ${ }^{158}$ The insights of survivors are instructive in understanding the barriers that can prevent people facing forced marriage from seeking help as well as the limitations of existing legal responses.

Most participants' vision of a just outcome existed outside the criminal justice framework. When asked what a just outcome would look like in their case, most interviewees $(n=6)$ expressed a desire that family members who supported the marriage would, at some point in the future, recognise that their actions were wrong, but did not want to see family members prosecuted. All interviewees believed that forced marriage was wrong and spoke of the validation they experienced when they realised that what was happening to them was against the law. While interviewees generally supported the criminalisation of forced marriage, the majority of interviewees $(n=5)$ indicated that they decided not to, or were reluctant to, approach the police for help due to fears about their safety or the safety of family members or because they did not want to expose family members to a criminal investigation. ${ }^{159}$

Most survivors' ideas about justice were linked to their desire to see others family, officials, the community - recognise the harm caused by forced marriage, ${ }^{160}$ rather than the outcome of a criminal justice process. Interviewees spoke about

157 This is consistent with earlier research. See, eg, Lyneham and Bricknell (n 33).

158 Committee on the Elimination of Discrimination against Women, Concluding Observations on the Eighth Periodic Report of Australia, $1602^{\text {nd }}$ and $1603^{\text {rd }} \mathrm{mtg}$, UN Doc CEDAW/C/AUS/CO/8 (25 July 2018) [25]-[26].

159 For instance, while Interviewee 5 did not report her situation to the police, she felt it was appropriate for the law to state a forced marriage was 'not a proper marriage', observing that the criminalisation of forced marriage was consistent with the prohibition of forced marriage under Islamic law. See also Australian Muslim Women's Centre for Human Rights (n 32) 12. These findings echo earlier qualitative studies: see, eg, Gill, Cox and Weir (n 57); Gangoli, Bates and Hester (n 79).

160 This aligns with an earlier study of survivors of slavery who linked their own ideas of justice to social justice and the process of recovery and restoration: Andrea Nicholson, Minh Dang and Zoe Trodd, 'A Full Freedom: Contemporary Survivors' Definition of Slavery’ (2018) 18(4) Human Rights Law Review 689. 
wanting to bring the truth to light, their hope that family members would recognise the harmful impact of forced marriage and that what had been done to them was wrong, their desire to 'undo' or 'rectify' the wrong against them by being 'put on the right path' where 'they' re not being forced or pushed or feeling unsafe', and the importance of frontline responders acknowledging the impact of forced marriage. ${ }^{161}$ Some interviewees hoped that, by changing the views of family members, they would protect siblings from a similar experience. One participant described how, since her divorce, her father's views had evolved - he was now something of 'a feminist' - and she now felt that not only was she free to make her own choices about her marriage, her younger sisters were too. ${ }^{162}$ Only two interviewees linked their own concept of justice to the outcome of a prosecution, with one participant stating that justice would be 'prosecuting whoever did it to you' and 'making them understand that it was the wrong thing to do'. ${ }^{163}$

This study reinforces concerns that the narrow referral pathway to the STPP may deter some people facing forced marriage from seeking assistance. ${ }^{164}$ Participants' fears about approaching the authorities were intertwined with uncertainty about the impact of reporting on their physical and financial security as well as the fear of losing familial relationships or endangering other family members. Under the current referral process, the AFP has the exclusive and non-reviewable power to determine who is a suspected victim of forced marriage and who has access to the STPP. While the AFP's role as the gatekeeper to the STPP enables the AFP - who can potentially provide intelligence and support at transit points out of Australia - to assist with safety planning, if people at risk are unwilling to have contact with the AFP, safety planning may never occur. Critically, the support offered by the STPP (including accommodation, financial support, and referrals to specialist legal services) remains out of reach. ${ }^{165}$ Where a forced marriage has not yet happened, the AFP states it engages in disruption activities, ${ }^{166}$ which can involve removing a person from a situation where they are at risk, ${ }^{167}$ making referrals to the STPP or to other agencies or services, placing the person at risk on a family law watchlist, ${ }^{168}$ 'speaking with, or empowering, potential victims and providing

161 Interviewee 6.

162 Interviewee 2.

163 Interviewee 4.

164 The accounts of participants in this study support an evaluation of the STPP Forced Marriage Stream Trial, which recommended expanding referral pathways to the STPP on the grounds that 'the high level of fear associated with the police' can effectively deter people from accessing support: Stacey and Boniface (n 49) 16.

165 'Support for Trafficked People Program' (n 22). As noted above, although the STPP is now available to forced marriage survivors for up to 200 days irrespective of whether they are willing to assist the police, contact with the AFP is still necessary to obtain a referral to the STPP.

166 Annual Report 2018-19 (n 35) 35. The AFP has highlighted the importance of disruption, deterrence, and supporting those who are at risk of forced marriage: Kelly Burke, 'Federal Police Launch Advertising Blitz at Sydney Airport on Forced Marriage’, 7News (online, 15 October 2019) <https://7news.com.au/ news/crime/federal-police-launch-advertising-blitz-at-sydney-airport-on-forced-marriage-c-504265>.

167 Lyneham and Bricknell (n 33) 52.

168 'Family Law Kit', Australian Federal Police (Web Page) < https://www.afp.gov.au/what-we-do/crimetypes/family-law-kit>; Joint Committee on Law Enforcement, Parliament of Australia, An Inquiry into Human Trafficking, Slavery and Slavery-Like Practices (Report, 18 July 2017) [5.23]. Alternatively, the 
them with strategies for protecting themselves' or, if the AFP deems it appropriate, 'speak[ing] with an affected person's parents ... before an offence occurs' ${ }^{169}$ However, there is a lack of publicly available data about the impact of the AFP's disruption activities or what happens to people after they are exited from the STPP. Greater scrutiny of referral mechanisms and support services would assist in understanding the impact of disruption activities by the AFP and mapping potential referral pathways in cases where individuals do not want to engage with the police or the STPP. Consideration should also be given to whether other government agencies or non-government organisations could play a role in referring suspected cases to the $\mathrm{STPP}^{170}$ or should be funded to engage in case-specific prevention activities that are separate to the STPP.

While it is necessary to look beyond the criminal justice system to develop preventative and protective strategies, it is important not to foreclose on the possibility that, in some cases, the criminal justice system might be a site of justice, accountability and redress for victims and their family. ${ }^{171}$ For instance, for one interviewee, the failure of the police to investigate her parents for marrying her sisters when they were children was a failure of justice, and she strongly supported a criminal justice response in all cases involving children, pointing out that the harm associated with these marriages was criminalised by laws pre-dating the offence of forced marriage:

Prosecute, because that's child grooming, you're facilitating sex with a minor, because on their wedding night, that's what they're expected to do, and if it was any other situation, absolutely any other situation, that's a paedophile, they're arrested. ... [W] hat shocks me about this is I don't understand why, because these are people of colour, we're supposed to give concessions like, it's okay, it's a ceremony. It's really not. At the end of the day they're still grooming a minor, you're still facilitating sex with a minor and this is just even sadder because it's literally like you're sentencing them to a life of servitude and abuse under a man ... treat it like any other sex crime against a minor. ${ }^{172}$

Critics of the criminalisation of forced marriage have argued that, without successful prosecutions, prohibiting forced marriage will have little deterrent value, and that the fear of exposing family members to criminal sanctions may deter reporting. ${ }^{173}$ Conversely, it has been suggested that criminalisation sends the

AFP may create an alert on the Passenger Analysis Clear and Evaluation System for a person at risk of forced marriage, related to their investigation: 'I Want to Protect Myself from Being Forced to Marry', My Blue Sky (Web Page) <https://mybluesky.org.au/i_want_to_protect_myself_from_being_forced_to_ marry $/$ ?node $=1826 \&$ depth $=2>$. However, this alert does not prevent that person from travelling.

169 Emily Baker, 'Report Details Abuse of Forced Marriage Victims Living in Australia', Canberra Times (online, 1 July 2018) <https://www.canberratimes.com.au/national/act/report-details-abuse-of-forcedmarriage-victims-living-in-australia-20180628-p4zo8a.html >.

170 See, eg, Stacey and Boniface (n 49) 22, which recommends the expansion of referral pathways to the forced marriage stream of the STPP.

171 For example, the victim in the UK's first forced marriage conviction felt proud to have contributed to the criminal proceedings, after having been properly supported by her police liaison officer throughout the investigation and trial process: Gill and Gould (n 109) 97, 101.

172 Interviewee 4.

173 For an overview of the arguments for and against criminalisation in the context of the UK, see Haenen (n 77) $248-55$. 
message that those at risk of forced marriage 'can challenge their parents' actions and that they have the right to seek help and report forced marriage'. ${ }^{174}$ As noted above, most interviewees did not want to see their family members prosecuted but considered that forced marriage should be criminalised and that information about these laws better known. Some interviewees considered that criminalisation had potential utility as a 'bargaining tool' to challenge their families' actions, negotiate alternative outcomes and reaffirm their right to seek help and report the forced marriage to authorities, even if in reality they were unlikely to do so. ${ }^{175}$

Multiple participants emphasised the importance of raising awareness of the complex and diverse manifestations of forced marriage, education about the right to choose who you marry, and early intervention to prevent forced marriage from occurring in the first place. ${ }^{176}$ Two participants considered that knowing forced marriage was against the law at the time they were resisting their marriage would have given them confidence in explaining to family members that the proposed marriage was wrong because they did not consent. Other participants considered that criminalising forced marriage had the potential to change attitudes and raise awareness of its harmful impacts, noting some family members may not appreciate that their actions were against the law or may themselves be facing community pressure to ensure the marriage occurred. Another interviewee believed that there should be laws against forced marriage and emphasised the importance of 'more exposure about the issue', 'but not so much the word forced marriage' as education and awareness raising about the rights of women and girls at risk: what was important was 'early intervention' and 'empowering these young girls to understand that they do have the right to marry if they want to marry and you do have a choice ... You don't have to answer to your parents'. ${ }^{177}$

While the law can only ever be one part of a diverse range of strategies deployed to respond to forced marriage, ${ }^{178}$ civil remedies may offer a more flexible and accessible remedy than criminal sanctions. Consultation about how to improve civil protections should examine how civil remedies can respond to the protection needs of people facing forced marriage, while recognising that, in some circumstances, young people will wish to maintain family connections. Specifically identifying forced marriage as a form of family violence in relevant laws and policies may also improve identification of those at risk, and reduce the risk that victims may miss out on the benefit of legislative protections for victims of family violence. ${ }^{179}$ Further research is needed to understand how interventions to

174 Ibid 251-2.

175 See, eg, comments of interviewees 1,2 and 7.

176 For example, Interviewee 1 considered that 'social assumptions' about forced marriage were 'very very dramatic - like what they could see in the movies where ... someone was threatened at gun point or knife point [whereas] ... what happened in reality was nowhere near that dramatic, but it was a long-term coercion ...'

177 Interviewee 7 (emphasis added).

178 Gill and Anitha, 'Forced Marriage Legislation in the UK' (n 78) 137; Haenen (n 77) 255.

179 Simmons and Burn (n 53) 1003-4 (recommending that statutory definitions of family violence in the Migration Act 1958 (Cth) specifically identify forced marriage as a form of family violence). See also Askola (n 53) 998-9; Segrave (n 133) 127, 134. 
address modern slavery within intimate partner and family violence relationships and child abuse interact, and what level of protection they afford to those facing forced marriage, ${ }^{180}$ as well as the ways in which regulatory controls, particularly in the area of immigration law, may leave people vulnerable to coercion and threats and, in some cases, impede their ability to seek protection. ${ }^{181}$

\section{B Survivor-Informed Law and Policy Reform}

Australia's response to forced marriage has not been informed by the voices of survivors of forced marriage. ${ }^{182}$ At a national and international level, there is growing recognition that survivors of family violence ${ }^{183}$ and modern slavery ${ }^{184}$ should be given meaningful opportunities to inform and influence the design, implementation, monitoring and evaluation of measures to address these practices. Significantly, all of the interviewees believed that it was imperative that strategies to address forced marriage be informed by people with first-hand experience of forced marriage: participants considered that listening and learning from survivors could inform prevention and education initiatives, including with young people, religious leaders and communities; the training of frontline responders; the nature of support provided to victims; and the design and implementation of law and policy reform.

For instance, Interviewee 5 did not believe Australia would ever be able to solve a problem like forced marriage until 'they listen to people who have experienced it,

180 Gill, Cox and Weir (n 57) 591-2 note that secondary victims, such as the child(ren) of a forced marriage, require additional support options, including protection orders, safeguarding and ongoing care.

181 Consultations with frontline responders and stakeholders highlighted that women with irregular or temporary migration statuses face particular barriers to accessing legal protection, while participants in this study highlighted the risks involved in seeking to withdraw their sponsorship of partner visa applications. This aligns with earlier research which indicates that, if a person's immigration status is uncertain, it can create a 'conducive context' in which a person facing forced marriage feels unable to seek help: Chantler and McCarry (n 26) 105; Mulvihill et al (n 136) 647. See also recommendation 45 in Hidden in Plain Sight (n 14) [9.94] and Segrave (n 133) 127-9, 131.

182 In 2020, DFAT sought submissions on how Australia's modern slavery strategy could be informed by the voices of survivors: Department of Foreign Affairs and Trade, 'International Strategy on Human Trafficking and Modern Slavery' (Consultation Paper, March 2020) 2. Those submissions indicate civil society support for survivor-informed policy and program development in response to modern slavery: Law Council of Australia, Submission to Department of Foreign Affairs and Trade, International Strategy on Human Trafficking and Modern Slavery (11 May 2020) 20-1; International Justice Mission, Submission to Department of Foreign Affairs and Trade, International Strategy on Human Trafficking and Modern Slavery (June 2020) 13-14; Project Respect, Submission to Department of Foreign Affairs and Trade, International Strategy on Human Trafficking and Modern Slavery (April 2020) 17; Australian Lawyers for Human Rights, Submission to Department of Foreign Affairs and Trade, International Strategy on Human Trafficking and Modern Slavery (7 May 2020) 7.

183 See, eg, University of Melbourne, The Family Violence Experts by Experience Framework (Research Report, 2020); Royal Commission into Family Violence: Report and Recommendations (Report, March 2016) 100 .

184 Australian Government, National Action Plan to Combat Modern Slavery 2020-25 (n 69) 21, 28; Nicholson, Dang and Trodd (n 160); National Human Trafficking Training and Technical Assistance Center, Toolkit for Building Survivor-Informed Organizations: Trauma-Informed Resources and SurvivorInformed Practices to Support and Collaborate with Survivors of Human Trafficking as Professionals (Report, February 2018); Urmila Bhoola, Contemporary Forms of Slavery, Including its Causes and Consequences: Note by the Secretary-General, UN Doc A/73/139 (10 July 2018) [56]. 
they listen to their voice and what they're actually wanting'. Interviewee 8 felt that hearing from other survivors would help people facing forced marriage to 'open their eyes', before explaining she wanted to

help people who are in my situation to [become] stronger, to fight for themselves. It's okay if your family [is] not there for you, it's okay if they don't support you and you go against them and it's okay to fight for your rights.

Interviewee 4 suggested that survivors are best placed to understand the experience of those at risk of forced marriage, and that the formation of a survivor advisory group could also provide opportunities for survivors to use their expertise and obtain employment. Interviewee 1 considered survivors had an important role to play in increasing understanding of forced marriage, but to fulfil this role it would be helpful to have training on 'how to deal with [the] media and how to deal with the public'. Another interviewee identified that a small group of survivors could provide guidance on what interventions and support could help and that, while one person's experience was not the same as another

they can share experiences, share cultural experiences and then together come up with an idea of okay well if this was me this is what I would've liked to [do], what would've worked and because they've lived it they know ... what is going to help and what is the more likely series of events or what is the more practical cause of action. ${ }^{185}$

Interviewee 7 said she would be 'one million percent' behind an advisory group that enabled survivors to inform Australia's response to forced marriage, explaining that listening to the views of survivors

would be a huge benefit to the government, because these survivors can tell them ... well look no, this is what's happened. This is what has happened and this is what you can do to avoid it.

Interviewee 3 considered that police could benefit from hearing from survivors' perspectives about their interactions with law enforcement. ${ }^{186}$ Other participants highlighted that any systematic and sustained efforts to engage with survivors need to provide measures to preserve confidentiality, protect safety and avoid re-traumatisation, and ensure that different experiences are represented and recognised. ${ }^{187}$ Some participants also stressed that survivors should be compensated for their time and expertise, noting that this could also help establish financial independence and develop vocational skills.

This study underscores that a victim-centred response to forced marriage must be informed by the voices of survivors. Developing sustainable survivor-informed and led programs will require time and resources: while it is possible to identify general principles for trauma-informed and survivor-informed practice, programs need to be 'site-specific' to the nature of the human rights harms that survivors have experienced. ${ }^{188}$ Participation must be safe and voluntary, and recognise different

\footnotetext{
185 Interviewee 2.

186 The value of victims' perspectives in designing support services has also been highlighted by earlier qualitative studies with victims of honour-based violence in the UK: Gill, Cox and Weir (n 57).

187 Interviewee 7; Interviewee 3; Interviewee 2.

188 University of Nottingham Rights Lab, Voices: Ideas for Using Survivor Testimony in Antislavery Work (Report, October 2019) 5.
} 
experiences of help-seeking. For example, this study highlights that some people may find ways to avoid or leave forced marriages without any interaction with specialist or mainstream services. These experiences are easy to overlook because legal interventions to address forced marriage focus on sanctioning its occurrence or making orders to protect individuals who are at risk of forced marriage, and tend to rely on an 'over-simple dichotomy between coerced and consensual marriage'. ${ }^{189} \mathrm{In}$ contrast, a dialogue approach - conversations with communities affected by forced marriage - has the potential to address the underlying causes of forced marriage and to reshape and reimagine power relations within families and communities. ${ }^{190}$ Understanding the varied experiences and needs of people facing forced marriage is crucial to developing law reform and awareness-raising campaigns that facilitate help-seeking, as well designing support services ${ }^{191}$ providing resources to support survivors, ${ }^{192}$ and training frontline responders.

While legal remedies can only ever be one part of a suite of strategies to respond to forced marriage, ${ }^{193}$ protective legislation has not been designed to respond to specific harms associated with forced marriage and is under-utilised. While this study did not specifically canvas the introduction of FMPOs, it is noteworthy that participants were not initially aware that forced marriage was illegal or of any legal protection or support services. Most participants did not contemplate obtaining protection orders, while those who did $(n=1)$ or considered doing so $(n=3)$ were doubtful about their effectiveness. One interviewee did not believe, based on her experience as a social worker, that domestic violence orders could stop family members from finding her; another was surprised at the short duration for which they applied and the lack of opportunity they offered for rehabilitation. ${ }^{194}$ Some participants indicated that the confrontational nature of seeking an order against their family, in open court, deterred them from going through the process.

The limitations of legalistic responses to forced marriage, whether civil or criminal, point to the importance of 'open-ended' support that enables victims

189 Anne Phillips and Moira Dustin, 'UK Initiatives on Forced Marriage: Regulation, Dialogue and Exit' (2004) 52(3) Political Studies 531, 534.

190 Ibid 545. See also Zeweri and Shinkfield (n 78) 12-13 for further discussion on strengthening community strategies in dealing with forced marriage.

191 Gill, Cox and Weir (n 57) (arguing for the voices of both victims and practitioners to be heard in the design of priority services).

192 Multiple participants identified that they could support survivors by sharing their experience. A handbook for forced marriage survivors published in the UK includes a personal message written by a survivor: United Kingdom Forced Marriage Unit, Forced Marriage: A Survivor's Handbook (Handbook, 20 April 2020) 7 .

193 Gill and Anitha, 'Forced Marriage Legislation in the UK' (n 78) 137; Haenen (n 77) 255.

194 This is in contrast to, for example, parental responsibility contracts between a child protection agency, such as the NSW Department of Communities and Justice, and one or more of the primary carers of a child or young person. These contracts aim to improve parenting skills and encourage carers to take specific steps, such as attending a support service, counselling or drug testing, to support a case plan goal. In NSW, if an agreed target in the parental responsibility contract is breached, a contract breach notice may be filed in the Children's Court and there will be a rebuttable presumption made by the Court that the child or young person needs care and protection: 'Orders in Care and Protection Matters', NSW Department of Communities and Justice (Web Page) $<$ https://www.facs.nsw.gov.au/families/legal/careand-protection-proceedings/orders>. 
to 'feel empowered to take steps to change their circumstances'. ${ }^{195}$ The views of participants about domestic violence orders provide an insight into the lack of confidence those facing forced marriage may have in the capacity of legal system to protect them from harm. Civil remedies have the potential to support people to avoid or leave a forced marriage but that much will depend on their design and implementation, which should include training for judges and support for applicants and witnesses. ${ }^{196}$ This underscores the need to invest in consultation with survivors and frontline services about any proposal to introduce a federal scheme of FMPOs, including the utility of third-party applications. However, legal remedies may not always serve the objectives or needs of people at risk of forced marriage and some may struggle to make sense of their experiences and relationships within the legal framework to address forced marriage. ${ }^{197}$ Consultations with survivors should inform the development of a range of preventative and protective strategies and pay close attention to the outcomes people at risk of forced marriage want to achieve. Programs that seek to understand the perspectives of survivors must be appropriately resourced and should inform strategies to protect the autonomy and safety of people who do not want to be involved in criminal or civil proceedings, ${ }^{198}$ community-led prevention initiatives, training for frontline responders, ${ }^{199}$ and in what circumstances support services should be withdrawn or alternative support options presented..$^{200}$

\section{CONCLUSION}

This study reinforces that forced marriage is best understood as 'a process rather than an event', ${ }^{201}$ involving complex and varied forms of coercion that occur over a prolonged period of time. Effective laws and programs to prevent and address forced marriage must be multifaceted and nuanced, capable of responding to survivors' individual experiences and objectives. Preventive and protective measures must be prioritised with attention paid to legal and social measures: first, by ensuring that legal responses facilitate the identification, protection and restoration of victims; and second, by investing in survivor-informed services and strategies that protect and promote the safety, autonomy and objectives of people facing forced marriage and strengthen the capacity of families and communities to identify and prevent forced marriage. While it is necessary to recognise the limitations of punitive responses to forced marriage and consider how civil

195 Gill, Cox and Weir (n 57) 590.

196 Noack-Lundberg, Gill and Anitha (n 74). The authors undertook a study of 33 judgments in FMPO matters and recommended expanded judicial training on the impact of trauma and disability on the evidence given by witnesses, as well as training that dismantles 'myths and stereotypes about the role of culture and tradition in specific forms of violence and abuse'.

198 Gill, Cox and Weir (n 57) 587-8.

199 Noack-Lundberg, Gill and Anitha (n 74). See also Haenen (n 77) 250.

200 Victims may need long-term support and safeguarding, particularly where there are ongoing child custody or contact disputes with an abusive partner: Gill, Cox and Weir (n 57) 590-2.

201 Chantler and McCarry (n 26) 95. 
remedies can protect those at risk from harm, the law alone cannot transform the inequalities and socio-cultural practices which lead to forced marriages or provide people with a safe environment to recover from the harmful impacts of forced marriage. Reform must be holistic and survivor-informed, addressing the barriers that prevent people facing forced marriage from accessing legal remedies and support services, and supporting those at risk to make autonomous decisions about their future. Grappling with the realities of forced marriage requires creating meaningful opportunities for survivors to shape the development and evaluation of preventative and protective measures. 